\title{
IDŐJÁRÁS
}

Quarterly Journal of the Hungarian Meteorological Service

Vol. 125, No. 1, January-March, 2021, pp. 53-82

\section{A statistical analysis of the relationship between domestic hot water consumption and mean outdoor temperature in Budapest}

\author{
András Horkai * \\ Óbuda University \\ Ybl Miklós Faculty of Architecture and Civil Engineering \\ H-1146 Budapest, Thököly út 74. \\ *Corresponding author E-mail: horkai.andras@hotmail.com
}

(Manuscript received in final form April 22, 2020)

\begin{abstract}
This study analyzes how outdoor temperature influences domestic hot water consumption in multiapartment large-panel system buildings in Budapest, Hungary. The analysis is based on data from the validated invoicing system of the district heating provider, and from two weather stations of the Hungarian Meteorological Service. The official monthly hot water consumption data of 72 buildings for 7 consecutive years and the corresponding monthly mean temperatures were used in this study. Linear regression analysis and time series decomposition were carried out. The results prove that the outdoor temperature and the domestic hot water consumption are definitely related. The model based on regression analysis could account for $74 \%$ of values. The time series decomposition model is able to estimate hot water consumption per apartment per day for a future month with $94 \%$ probability. The study relies on data obtained from a projection of two regional climate models each, namely ALADIN-Climate and RegCM. Based on these data, the model forecasts how the effects of climate change will probably influence domestic hot water consumption in the near future. These results shed light on the factors influencing hot water consumption, and may help authorities and decision makers to form sustainability policies and to plan sustainable resource management.
\end{abstract}

Key-words: Budapest, climate, domestic hot water, household, mean outdoor temperature, statistical data analysis, water consumption 


\section{Introduction}

The complex energy system and energy consumption of buildings consists of several subsystems and their consumption, which is necessary for the intended use of the building. In Hungary, the Decree of the Minister without Portfolio on the determination of the energy characteristics of buildings takes into account the consumption, efficiency, losses, and self-consumption of all building engineering systems necessary for the intended use of the building when determining the aggregate energy characteristics (which is the sum of the primary energy consumption of building engineering and lighting systems per unit of heated floor area). These systems include: heating, domestic hot water supply, air technology, cooling, and lighting (7/2006. (V. 24.), Decree, 2006; Baumann et al., 2009).

Domestic energy consumption makes up $28 \%$ of overall energy use of the EU (based on data from 2017), while for Hungary this figure is 36\% (Eurostat; Magyar Energetikai és Közmü-szabályozási Hivatal). Looking at the average consumption structure of Hungarian households, two independent studies have reached similar results. $75 \%$ of the full energy expenditure is spent on heating and air-conditioning, $10 \%$ is spent on hot water production, while $10 \%$ is spent on the energy used by electrical appliances (e.g., consumer electronics, household appliances) (Energia Klub, 2004; Energiaoldal, 2012). In the USA, the proportion of hot water costs amounts to the $20 \%$ of full energy expenses (NAHB Research Center, 2002). In 2015 Hakala concluded that the second largest item in domestic energy balance is hot water production in Finland. Consequently, the production of domestic hot water (DHW) accounts for a significant proportion of the energy balance of residential buildings (Hakala, 2015). It must be noted, however, that the proportion of DHW consumption in the energy balance depends on several parameters, and consumer profiles are very complex and change over time (Ahmed et al., 2016).

Approximately $13 \%$ of the Hungarian housing stock is built with large-panel system (LPS) technology, and one-eighth of the population live in such type of flats (Központi Statisztikai Hivatal, 2014). Central heating and domestic hot water supply are provided by district heating in these houses. This study analyzes the domestic hot water consumption data of a housing estate built with large-panel system in Budapest, Hungary and the outdoor temperature in the course of several years. It aims to reveal how outdoor temperature change influences domestic hot water consumption in multiapartment buildings. More precisely, the study aims to map how DHW consumption and outdoor temperature are related, by breaking down the data into different spatial (full housing estate, certain building types) and temporal (year, season) figures. The results are used to predict future tendencies of DHW consumption. 


\section{Background}

\subsection{Factors influencing energy and water consumption}

Models of energy consumption influencing factors aim to determine how these factors can be categorized. Kowsari and Zerriffi (2011) established two major factor categories: (i) endogenous factors depend on the household examined; while (ii) exogenous factors depend on outdoor circumstances. The major categories are further divided into subcategories.

Based on the above holistic model, Putzer and Pavluska (2013) introduced the model illustrated in Fig. 1 to describe energy consumption (energy profile) for Hungary. All factors were included into the model that have shown a significant correlation with domestic energy consumption in the literature.

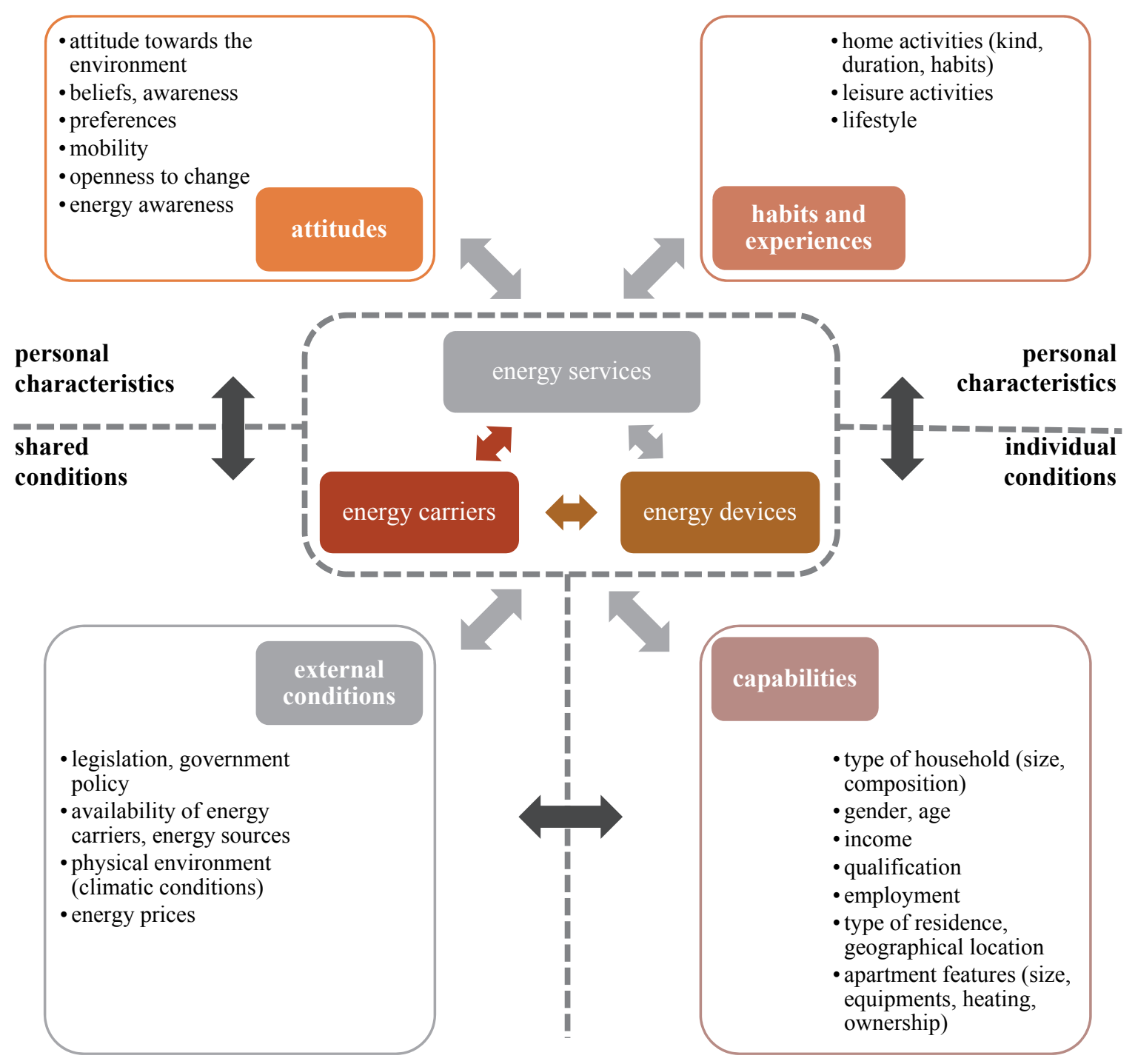

Fig. 1. Energy consumption model of Hungarian households - major influencing factors. Figure by the author based on Horkai and Kiss (2019). 
The model shows factors that affect energy use in general. Given that domestic hot water consumption is part of the total energy consumption, a significant proportion of the factors presented influence the energy use: physical environment and climatic factors - examined in the present article - have appeared as influencing factors in several other studies (Egyedi, 1963; Hobbi and Siddiqui, 2009; March and Saurí, 2010; Menyhárt, 1977; Otaki, 2003; PérezLombardet al., 2008). Contrarily to these, in their study on climatic and geographical factors, Romano et al. (2016) found that only the height above sea level had a significant effect on water consumption, temperature did not.

As for climatic factors, several studies point out that seasonality (i.e., tendencies shown by data in yearly, monthly, weekly, and daily breakdowns play a crucial role in DHW consumption (Abrams and Shedd, 1996; Becker and Stogsdill, 1990b; Csoknyai and Csoknyai, 2014; Egyedi, 1963; George et al., 2015; Gerin et al., 2014; Horkai, 2019; Menyhárt, 1977; Meyer, 2000; Perlman and Mills, 1985). Details of the research can be found in Section 5.2.2.

\subsection{Climatic conditions of Hungary}

Hungary is situated in the northern continental climate zone, characterized by four seasons and westerlies. The weather is rather changeable owing to the fact that the country is affected by oceanic, continental, and Mediterranean effects as well (Kocsis, 2018).

The most important factors influencing the temperature are as follows: (i) latitude; (ii) altitude; (iii) distance from the seas. The yearly mean temperature in the majority of the country is between $10{ }^{\circ} \mathrm{C}$ and $11^{\circ} \mathrm{C}$. Based on data between 1981 and 2010 , the national average is $10.4^{\circ} \mathrm{C}$. Mean temperatures above $11^{\circ} \mathrm{C}$ appear in the southern-southeastern parts of the country, on slopes with southern or southwestern exposure, and in Budapest owing to the urban heat island effect. It must be noted, however, that an extensive appearance of such high mean temperatures (above $11^{\circ} \mathrm{C}$ ) is only characteristic of the past 30 years (Kocsis, 2018).

According to the Köppen-Geiger climate classification system, the majority of Hungary belongs to the Dfb category (i.e., cold (continental), no dry season, warm summer), while the surveyed area is partly $\mathrm{Dfb}$ and Dfa (i.e., cold (continental), no dry season, hot summer) (Beck et al., 2018), see Fig. 2.

According to the local climate zones (LCZ) in Budapest defined by Gál et. al. (2015), the Füredi housing estate falls into the category LCZ 5 - open midrise. Dian et. al. (2020) compared these local climate zones with surface temperature satellite data. Based on their studies, it was found that in this category, SUHI (surface temperature-based urban heat island) is above $1^{\circ} \mathrm{C}$ throughout the year, with up to $4-5^{\circ} \mathrm{C}$ during the day in summer compared to non-urban areas outside Budapest. Thus, the Füredi housing estate belongs to the category of LCZ with the second highest SUHI in the capital. 


\section{Data}

\subsection{Description of the surveyed area}

The primary factor for selecting an area for analysis was to have available data about domestic hot water consumption from an authorized source. The metering of heating and domestic hot water consumption in buildings with district heating is general practice in Hungary, which allows for the detailed analysis of consumption data. For other types of buildings, such surveys would be impossible to carry out in the lack of appropriate data. The overwhelming majority of buildings provided with district heating are multiapartment LPS buildings in housing estates (Horváth et al., 2016).

More than a third of Hungarian LPS buildings are in Budapest (Birghoffer and Hikisch, 1994; Dési, 1996), therefore, the plot to be examined was selected in this city. The Füredi housing estate (Füredi út, district XIV) is the fifth largest housing estate of LPS buildings in the city. It was built in three phases between 1967 and 1978, using LPS technology (Berza, 1993).

The housing estate is made up of 83 buildings, out of which 72 were taken into this survey. As for the remaining 11 buildings, for some houses the data series provided by the public utility company were incomplete or missing, while others were excluded from this study owing to their crucially different energetic structure (e.g., solar collectors).

\subsection{Data on domestic hot water consumption}

Hong et al. (2017) warns that it is advisable to use data from an integrated source (e.g., energy consumption data from the public utility company) for the analysis of consumers and consumer habits. It is equally important to note that if data is collected directly from consumers, the inconsistency between real and reported habits might be a limitation of data collection (Young et al., 2013). Based on these policies, this study does not use data obtained directly from consumers. It relies on quantitative data provided by the public utility company and found in the official census, and only this dataset is used for a statistical analysis of the relationships between different variables.

For the present study, the district heating provider (FÖTÁV Budapesti Távhőszolgáltató Zrt. - Budapest District Heating Works Private Company Limited by Shares) provided the consumption data broken down to the primary heat substations of each building, both for heating and domestic hot water for the time period between 2010 and 2016, in monthly breakdown. These datasets had served as the basis for accounting after automatic or manual checking, i.e., the sets can be regarded as official and validated. The basic unit of this analysis is the building. If there is more than one heat substation in a given building, the relevant datasets were collapsed. 
According to information from the district heating provider, the buildings can be regarded as uniform with respect to the domestic hot water providing system, there is no significant difference between them. The present study does not take into account whether the building envelope was refurbished.

\subsection{Temperature data}

The mean temperatures in monthly breakdown were taken at two weather stations (Budapest-Pestszentlörinc and Budapest-Inner City) of the Hungarian Meteorological Service (OMSZ). The averages of the two datasets were used in this study. The air distance of the two weather stations from the examined plot is approximately $8.75-9.00 \mathrm{~km}$.

Fig. 2 shows the climate classification map of Hungary, Budapest, and the surveyed area (based on the Köppen-Geiger system), as well as the location of the weather stations and the Füredi housing estate within Budapest.
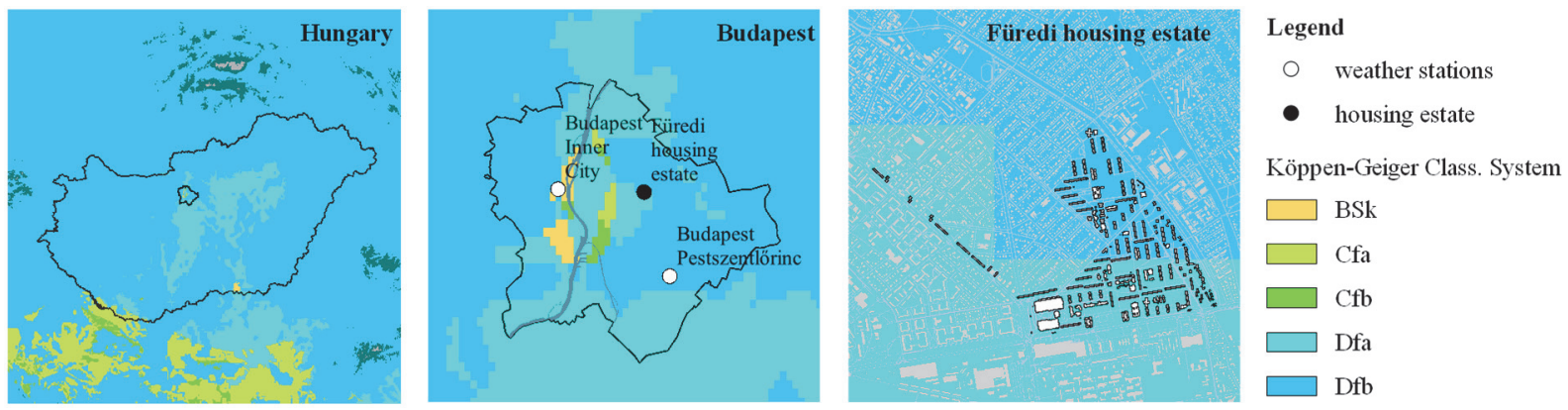

Fig. 2. Weather stations and the surveyed area on a climate classification map based on the Köppen-Geiger system (Beck et al., 2018).

\subsection{Basic data from climate projections}

Temperature data for the estimation of future domestic hot water consumption were obtained from the National Adaptation Geo-Information System (NAGiS). This database was created from data gained from the CarpatClim-Hu databasewhich resulted from validated and homogenized meteorological measurement data interpolated on a regular grid, and harmonized at the borders; furthermore, from data resulting from a projection of models ALADIN-Climate (Csima and Horányi, 2008) and RegCM (Sitz et al., 2017), respectively. Climate model projections were created with Representative Concentration Pathway (RCP) scenarios. These scenarios take into consideration the international mitigation initiatives, which are characterized by the possible range of radiative forcing values in the year 2100. In this study, we used the pessimistic RCP8.5 scenario for ALADIN-Climate, while for RegCM the optimistic RCP4.5 scenario was used to create the model simulations (i.e., supposing 8.5 and $4.5 \mathrm{~W} / \mathrm{m}^{2}$ radiative forcing 
for 2100, respectively). Their data correspond to the periods 1971-2000, 20212050, and 2069-2098. Naturally, model simulations are loaded with insecurity resulting from the natural changeability of climate, the fact that physical processes can be described with a limited precision, and the unpredictability of social and economic processes that exercise an effect on the system (Kajner et al., 2017; Nemzeti Alkalmazkodási Térinformatikai Rendszer (NATéR) - ENG: National Adaptation Geo-information System (NAGiS)).

Based on the results of the two models, the raising of the mean temperature in Hungary will continue, concerning both monthly and yearly averages. Between 2021 and 2050, the predicted growth is $1-2^{\circ} \mathrm{C}$ for the end of the period, while for the end of the $2071-2100$ period, it is $3-5^{\circ} \mathrm{C}$. It is not straightforward which seasons will change the most. For the middle of the century, the ALADIN-Climate model predicts the greatest changes for the summers, while the RegCM model claims the spring mean temperatures are to raise considerably (Kajner et al., 2017).

Table 1 shows the expected change in the yearly mean temperatures for the periods 2021-2050 and 2071-2100, based on the projections of climate models ALADIN-Climate and RegCM, compared to the period between 1961 and 1990. The values shown here are the differences between mean temperatures in the two periods.

Table 1. Predicted changes in yearly mean temperature $\left({ }^{\circ} \mathrm{C}\right)$ in Hungary based on projections of ALADIN-Climate and RegCM climate models compared to period 1961-90 (Nemzeti Alkalmazkodási Térinformatikai Rendszer (NATéR) - ENG: National Adaptation Geo-information System (NAGiS))

\begin{tabular}{lcccc}
\hline \hline model & \multicolumn{2}{c}{ ALADIN-Climate (RCP8.5) } & \multicolumn{2}{c}{ RegCM (RCP 4.5) } \\
\hline period & $\mathbf{2 0 2 1 - 2 0 5 0}$ & $\mathbf{2 0 7 1 - 2 1 0 0}$ & $\mathbf{2 0 2 1 - 2 0 5 0}$ & $\mathbf{2 0 7 1 - 2 1 0 0}$ \\
\hline \hline year & $1.5-2.0$ & $3.0-3.5$ & $1.0-1.5$ & $3.0-3.5$ \\
winter & $1.0-1.5$ & $2.0-2.5$ & $1.0-1.5$ & $3.0-3.5$ \\
spring & $1.5-2.0$ & $3.0-3.5$ & $1.5-2.0$ & $2.5-3.0$ \\
summer & $2.0-2.5$ & $4.0-4.5$ & $0.5-1.0$ & $3.5-4.0$ \\
autumn & $1.5-2.0$ & $3.0-3.5$ & $0.5-1.0$ & $3.0-3.5$ \\
\hline
\end{tabular}

\section{Methods}

\subsection{Levels of analysis}

Owing to the availability and detailedness of the data, this analysis examines domestic hot water consumption broken down to different spatial (whole housing estate, certain building types) and temporal (year, season, month) levels. It does not differentiate between buildings before or after energetic refurbishment; the 
domestic hot water systems of these buildings are treated uniformly based on the resolution of the district heating provider.

Altogether 72 buildings (11,211 apartments) were surveyed. Building types in which the total number of apartments reaches $10 \%$ of the total number of flats in the housing estate: Types $\mathrm{K} 1, \mathrm{~K} 2$, and $\mathrm{Kx} 4$ (see Table 2 for the parameters of these building types) were chosen for the building type level analysis.

Table 2. Parameters of the surveyed building types (Horkai et al., 2018)

\begin{tabular}{|c|c|c|c|}
\hline \multirow[b]{2}{*}{ type } & K1 & K2 & $\mathrm{Kx4}$ \\
\hline & & & \\
\hline $\begin{array}{l}\text { number of apartments } \\
\text { per building }\end{array}$ & 132 & 264 & 172 \\
\hline $\begin{array}{l}\text { weighted average size } \\
\text { of apartments }\left[\mathrm{m}^{2}\right]\end{array}$ & 48.90 & 45.60 & 58.88 \\
\hline $\begin{array}{l}\text { weighted average } \\
\text { number of rooms per } \\
\text { apartment }\end{array}$ & 2.33 & 2.00 & 2.51 \\
\hline heated volume $\left[\mathrm{m}^{3}\right]$ & 16,900 & 31,400 & 26,000 \\
\hline
\end{tabular}

In sum, the survey examines the whole housing estate, certain building types, and the cumulative parameters of all other building types. Fig. 3 illustrates this hierarchy.

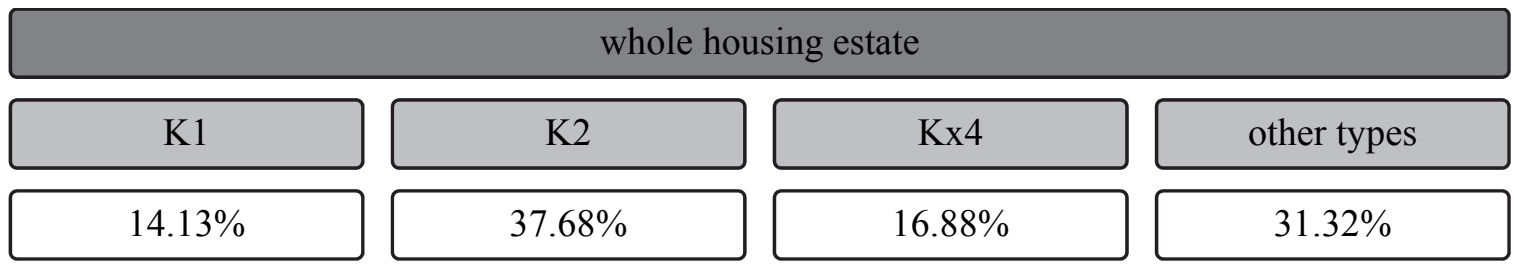

Fig. 3. Hierarchy and distribution of apartments in building types in the housing estate. 


\subsection{The parameters examined}

The data on DHW consumption were given in $\mathrm{m}^{3} /$ building/month by the district heating provider. Similarly to other studies (Energy Monitoring Company, 2008), in order to eliminate the differences in building types (i.e., a different number of apartments) and the length of the months, the data series was normalized and the unit of consumption was changed to 1/apartment/day (henceforth 1/apt/day). Concerning the number of hot water taps, each flat in the housing estate (irrespective of size) is equipped with a wash basin and a bathtub in the bathroom, and a sink in the kitchen.

No data is available on the number of inhabitants of individual flats or houses, only detailed demographic data available on $\sim 35 \%$ of the housing estate (3960 dwellings) can be used to deduce the average density of housing, which is 1.53 people per apartment. It must be noted that this number is well below (almost 38 percentage points lower, than) the national average, which is 2.48 person/apartment (Központi Statisztikai Hivatal, 2014).

On the one hand, the low density of the dwellings can be explained by the location. In fact, nearly $40 \%$ of residential dwellings in the capital are occupied by people living alone (compared to $30 \%$ of the national average). Furthermore, in Hungary, as we go down the hierarchy of settlements, apartments become more densely populated: Budapest has the lowest density ratio with 2.13 people/apartment. This number is 2.35 in county capitals and county towns, 2.57 in other cities, and 2.72 in municipalities (Központi Statisztikai Hivatal, 2014).

The low density of apartments, on the other hand, can be explained by the age structure. The number of residents over 60 years of age in Füredi housing estate is higher than the national average, and nearly $30 \%$ of the over- 65 s live in a single household in Hungary (Balázs et al., 2017).

\subsection{Statistical methods}

The available data was analyzed with the help of MS Excel. The normality of the data set was examined using the Kolmogorov-Smirnov test.

The correlations between DHW consumption and weather data were explored with the help of regression analysis with two variables: in our model the independent variable was the monthly mean temperature, while the dependent variable was the domestic hot water consumption.

Time series were analyzed with decomposition methods, aiming to find the following components of time series.

- Trend $\left(\mathrm{T}_{\mathrm{t}}\right)$ : long-term direction of the basic time series, i.e., what tendency can be quantified in the time series taken as a function of time.

- Seasonality $\left(\mathrm{S}_{\mathrm{j}}\right)$ : regularly recurring short-term (within a year) deviations from the trend (i.e., regular fluctuations). 
- Random component $\left(\mathrm{E}_{\mathrm{t}}\right)$ : part not explained by either the trend or seasonality, random effect.

The first step of the time series decomposition was to model the trend with a linear regression function, where the explanatory variable was the passage of time (from January 2010 to December 2016, broken down to months). In the next step, the estimated values were subtracted from the actual measured data, which gave the sum of seasonality and random components. In step 3, averages were calculated and corrected to arrive at the pure seasonal values. The aim of correction was to make the mean of seasonal effects zero, in order that it should not contain tendencies. Pure seasonal values show the deviations from the trend of the given month.

\section{Results and discussion}

\subsection{Statistical parameters of the basic dataset}

The statistical parameters of the basic datasets corresponding to 84 months are given in Table 3.

Table 3. Statistical parameters of the basic datasets

\begin{tabular}{lcccccc}
\hline \hline & $\begin{array}{c}\text { outdoor } \\
\text { temperature } \\
{\left[{ }^{\mathbf{0}} \mathbf{C}\right]}\end{array}$ & $\begin{array}{c}\text { Dhole housing } \\
\text { estate }\end{array}$ & $\mathbf{K 1}$ & $\mathbf{K 2}$ & $\mathbf{K x 4}$ & $\begin{array}{c}\text { other } \\
\text { types }\end{array}$ \\
\cline { 3 - 7 } $\mathbf{N}$ & 84 & 84 & 84 & 84 & 84 & 84 \\
Sum & 1059.60 & 7588.01 & 7362.50 & 6987.46 & 7749.91 & 8325.03 \\
Mean & 12.61 & 90.33 & 87.65 & 83.18 & 92.26 & 99.11 \\
Median & 13.00 & 93.33 & 90.08 & 85.95 & 95.05 & 101.00 \\
Min & -1.20 & 71.76 & 67.77 & 66.76 & 73.23 & 77.57 \\
Max & 25.10 & 103.72 & 102.02 & 95.27 & 103.17 & 115.78 \\
Deviation & 7.97 & 8.76 & 8.71 & 7.96 & 8.67 & 10.12 \\
Kurtosis & -1.29 & -0.41 & -0.43 & -0.49 & -0.26 & -0.38 \\
Skewness & -0.08 & -0.77 & -0.72 & -0.71 & -0.96 & -0.64 \\
\hline
\end{tabular}

The Kolmogorov-Smirnov normality test of the data proved that the distribution of sample elements does not significantly deviate from the normal distribution. 


\subsection{Analysis of hot water consumption}

\subsubsection{Decomposition models}

Figs. 4.(a-e) depict the decomposition models of the domestic hot water consumption of each unit of analysis.
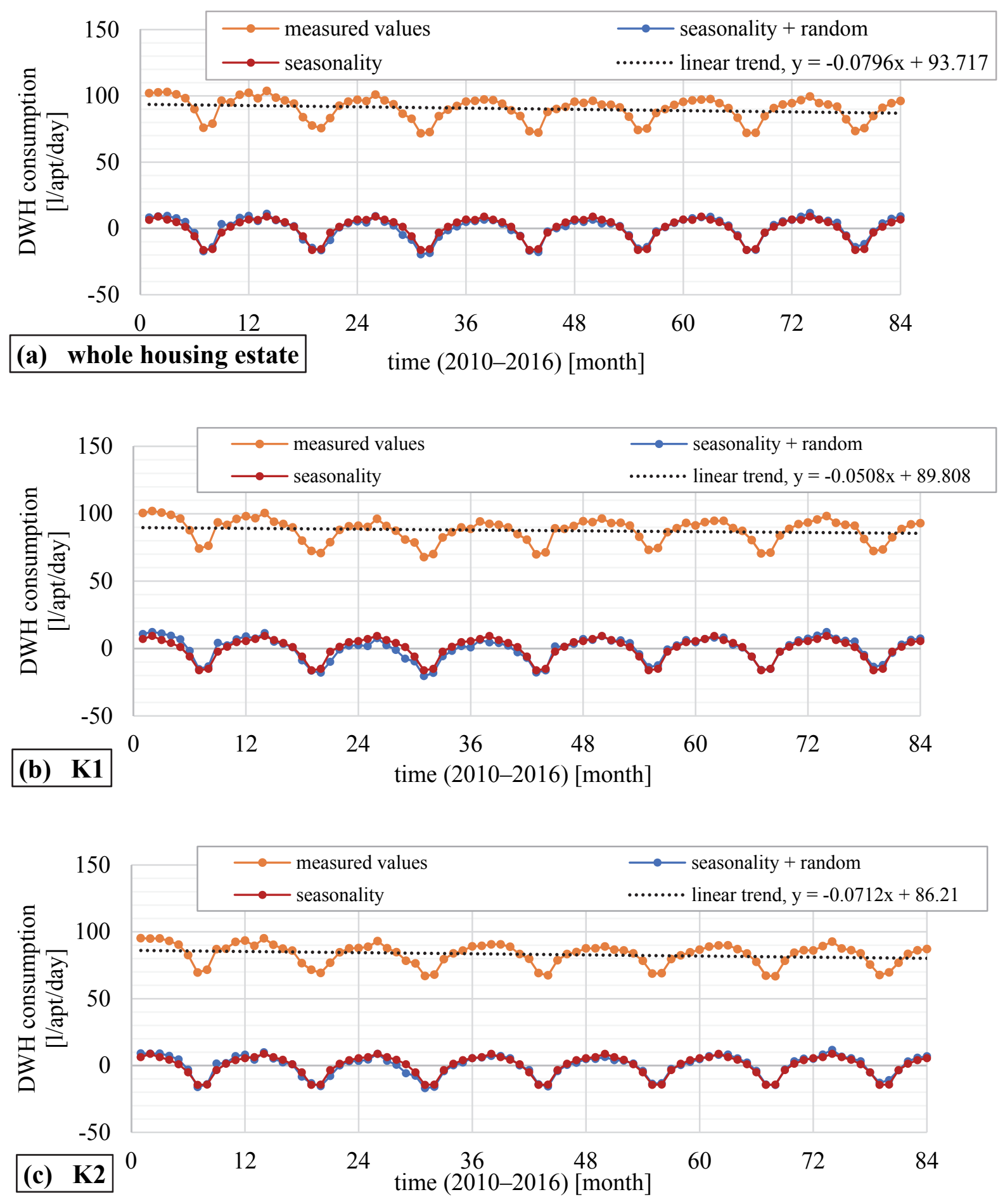

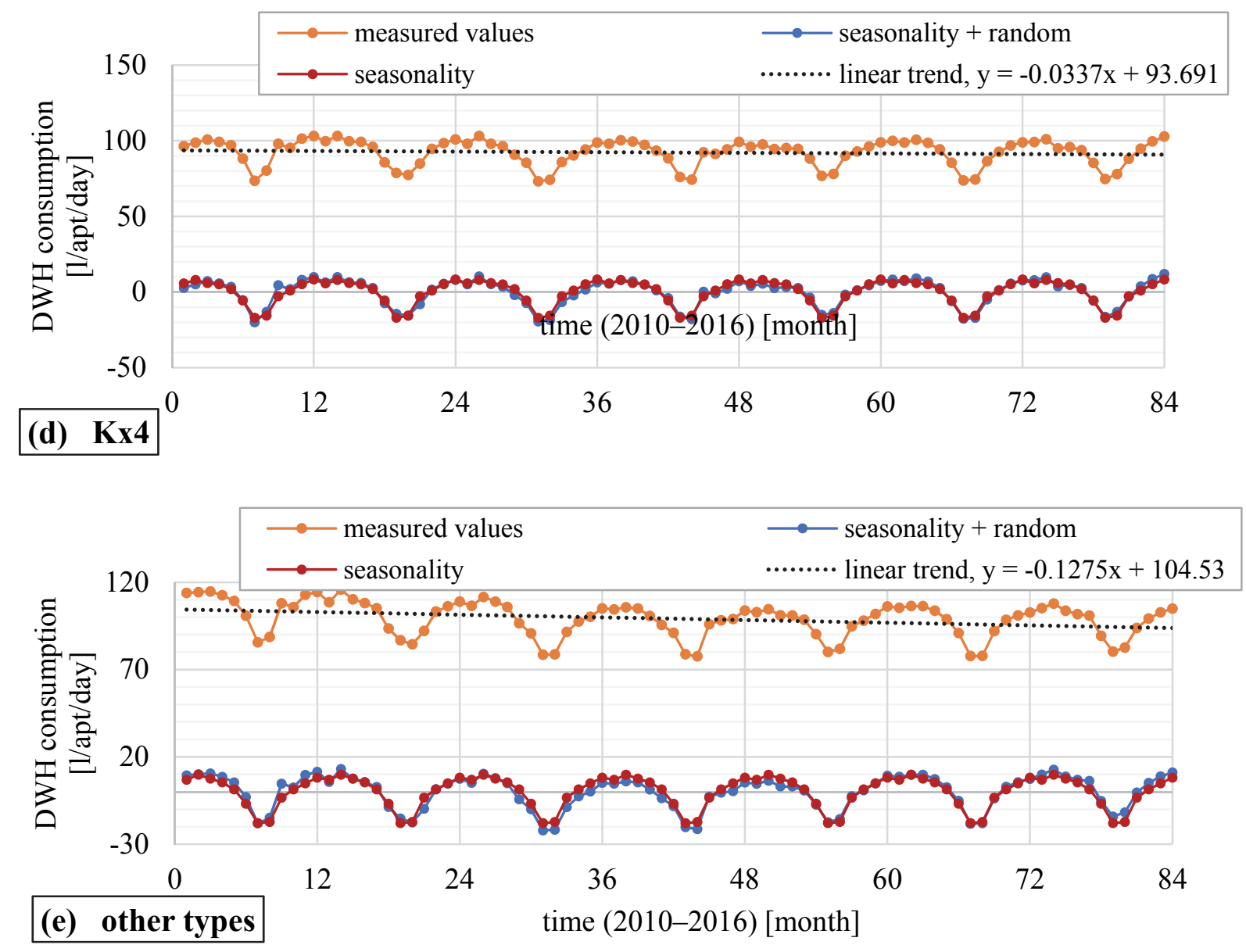

Fig. 4 (a-e). Decomposition models of the domestic hot water consumption of each unit of analysis.

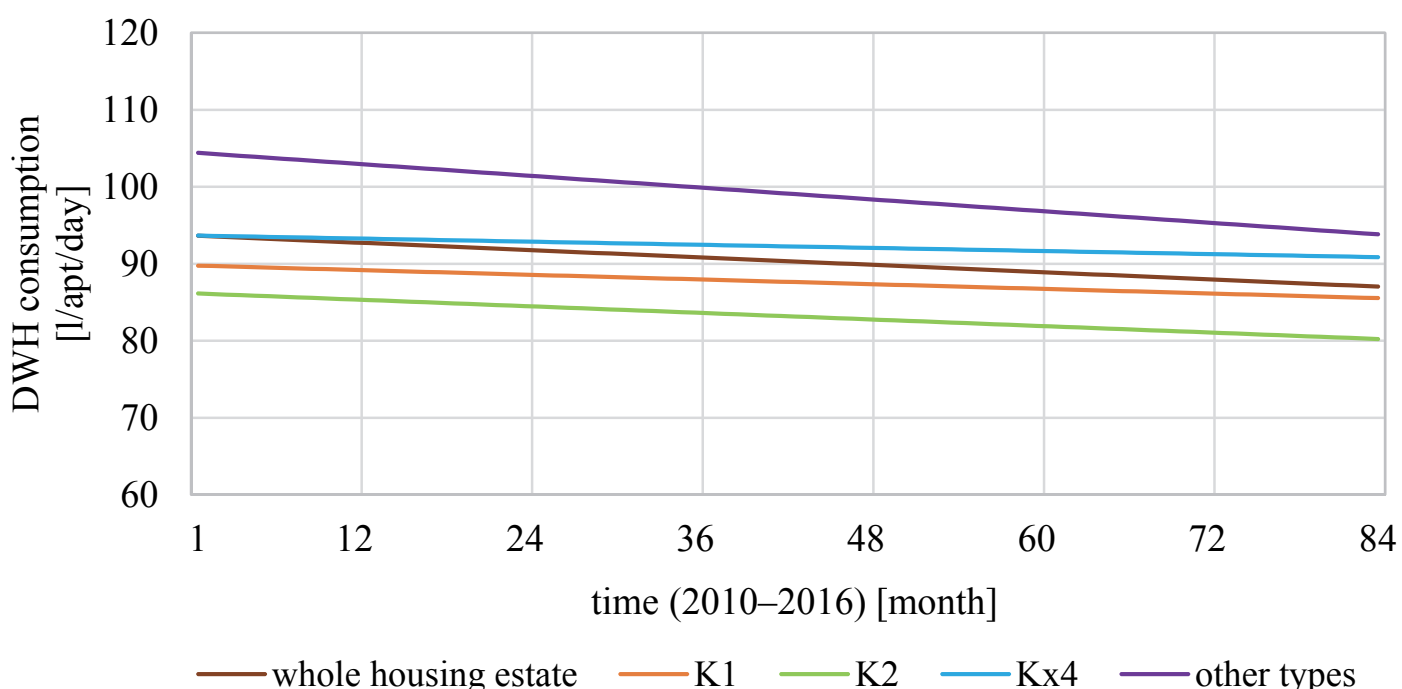

Fig. 5. Trends in hot water consumption in the surveyed period. 
The basic trends for 7 years of each survey unit are illustrated in the above figures: in the long run, DHW consumption decreased. The smallest basic domestic hot water consumption (1/apt/day) was recorded in Type $\mathrm{K} 2$ buildings, while the biggest basic consumption was recorded in Type $\mathrm{Kx} 4$. This difference in basic consumption may stem from several factors, such as the different size of apartments (which affects the number of inhabitants), distribution losses, the age of plumbing, the different behavior of consumers.

Concerning the slope of the trendlines, the consumption of $\mathrm{Kx} 4$ buildings decreased the least, while the decrease was the biggest for other and $\mathrm{K} 2$ buildings.

As Fig. 6 illustrates, a very similar seasonality effect is witnessed at all units of survey, as seasonality influences them in the same way. An inverse relationship is present between the outdoor temperature and DHW consumption, the corresponding curves change in the same fashion.

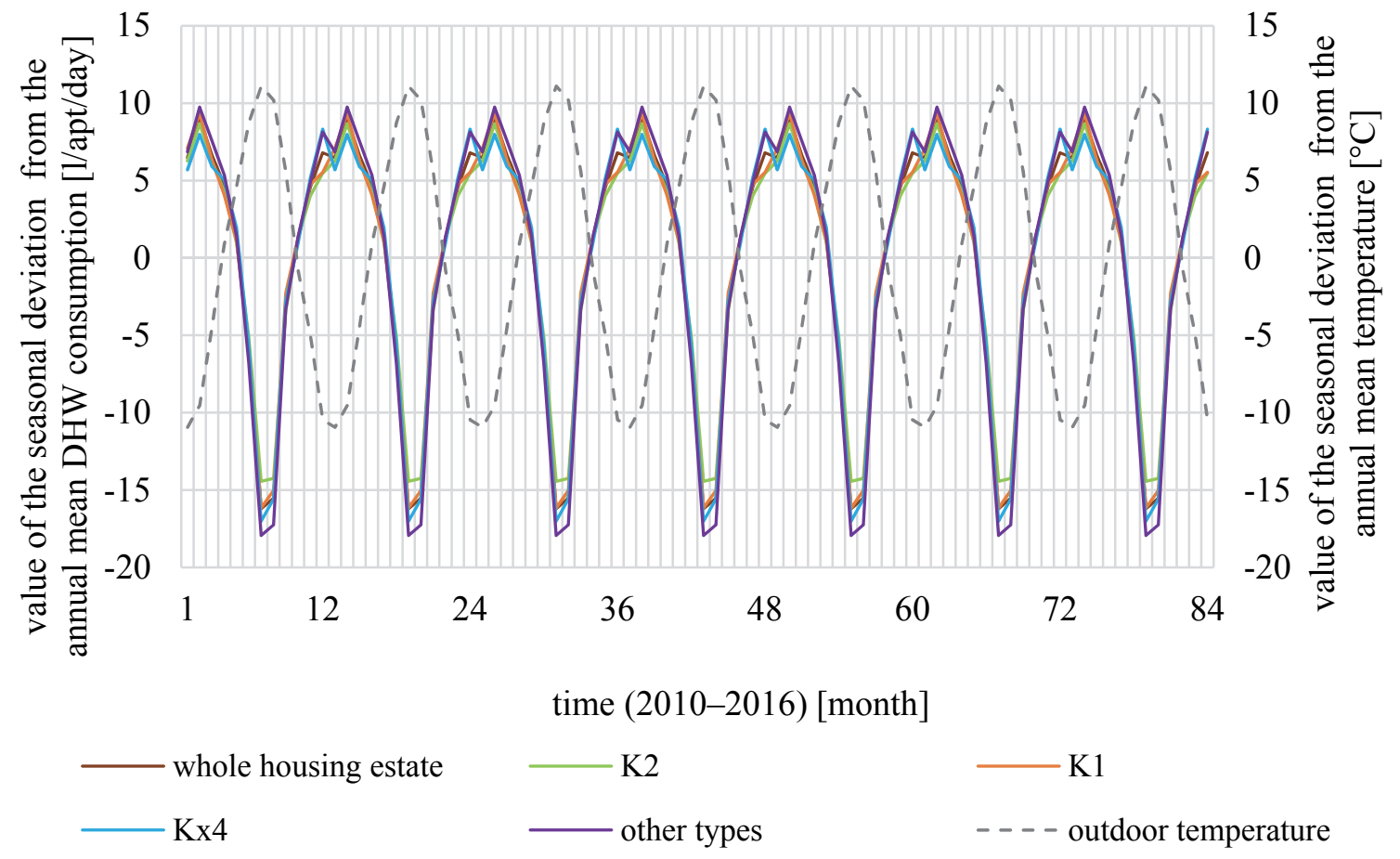

Fig. 6. Seasonality of outdoor temperature and DHW consumption 


\subsubsection{Consumption broken down to seasons}

The average DHW consumption of units in the whole survey period (2010-2016) and also broken down to months are given in Table 4.

Table 4. Average and seasonal DHW consumption (average of years 2010-2016)

\begin{tabular}{cccccc}
\hline \hline 1/apt/day & $\begin{array}{c}\text { whole housing } \\
\text { estate }\end{array}$ & K1 & K2 & Kx4 & other types \\
\hline \hline winter & 97.87 & 95.05 & 90.10 & 99.64 & 107.54 \\
spring & 94.74 & 91.59 & 87.20 & 96.63 & 104.21 \\
summer & 77.77 & 75.23 & 71.89 & 79.51 & 85.05 \\
autumn & 90.96 & 88.72 & 83.55 & 93.26 & 99.63 \\
\hline $\begin{array}{c}\text { average of the } \\
\text { period }\end{array}$ & 90.33 & 87.65 & 83.18 & 92.26 & 99.11 \\
\hline \hline $\begin{array}{c}\text { \% (expressed as an } \\
\text { average of years } \\
\text { 2010-2016) }\end{array}$ & whole housing & K1 & $\mathbf{K 2}$ & $\mathbf{K x 4}$ & other types \\
\hline \hline $\begin{array}{c}\text { winter } \\
\text { spring }\end{array}$ & 108.34 & 108.44 & 108.31 & 108.00 & 108.51 \\
summer & 104.88 & 104.50 & 104.82 & 104.74 & 105.14 \\
autumn & 86.09 & 85.83 & 86.42 & 86.18 & 85.82 \\
\hline $\begin{array}{c}\text { average of the } \\
\text { period }\end{array}$ & 100.69 & 101.23 & 100.44 & 101.08 & 100.53 \\
\hline
\end{tabular}

Fig. 7 shows the average and seasonal DHW consumption of each unit of analysis.

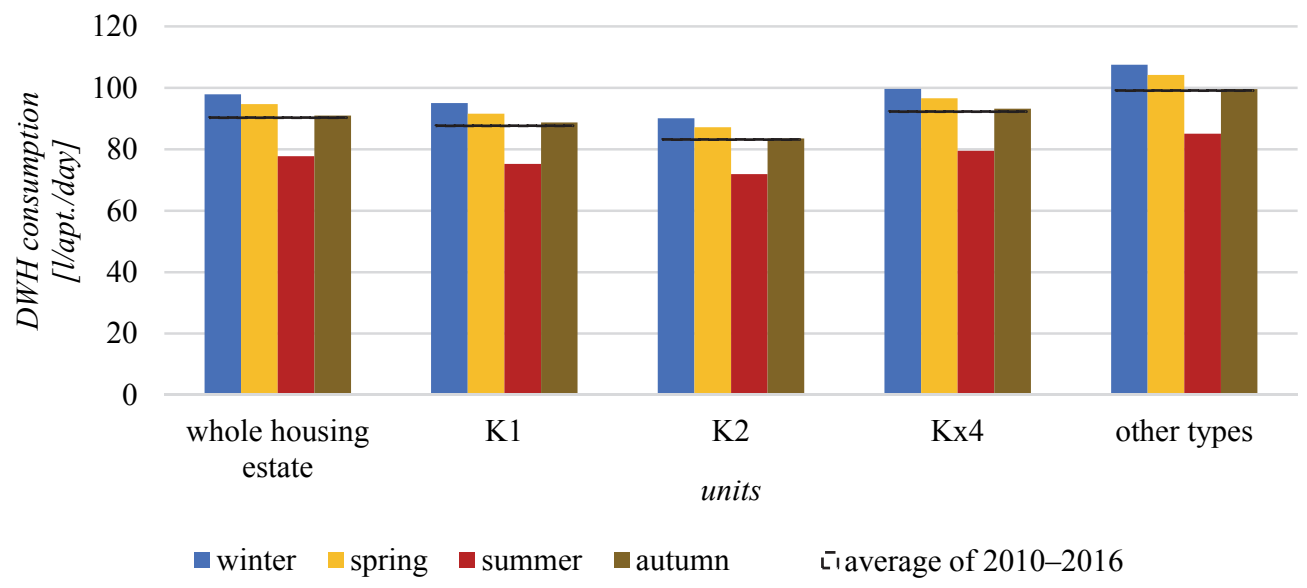

Fig. 7. Average and seasonal DHW consumption (average of years 2010-2016) 
The data proves that domestic hot water consumption changes considerably within a year: the highest consumption was recorded in winter, which is 8 percentage points higher than the average, while summer consumption is 14 percentage points lower than the yearly average of the surveyed period. Consequently, the difference between winter and summer consumption is 22 percentage points. Autumn consumption roughly equals the yearly average.

Several Hungarian and international studies confirm that seasonality effect DHW consumption. Egyedi (1963) found a 16-22\% difference between winter and summer consumption. Menyhárt also states that weather is the primary factor in influencing water consumption and that consumption is periodic within the year, month, week and day (Menyhárt, 1977).

Perlman and Mills found that winter DHW consumption might exceed summer consumption by 45\% (Perlman and Mills, 1985). According to Becker and Stogsdill seasonality is the main influencing factor for DHW consumption: winter consumption is higher than summer consumption (Becker and Stogsdill, 1990a, 1990b). The same authors found the average winter consumption to be 13\% higher than the average summer consumption (Becker and Stogsdill, 1990a). Meyer examined water consumption in South Africa, where the difference between summer and winter consumption might reach 37\% (Meyer, 2000). It must be noted that owing to the geographical situation of the country, in South Africa summer consumption is higher than winter consumption. Gerin et. al. (2014) surveyed the DHW consumption of Belgian apartments, and found that winter consumption was $12 \%$ higher and summer consumption was $13 \%$ lower than the average consumption.

In their study on heat and DHW consumption in LPS buildings in Hungary, Csoknyai and Csoknyai (2014) found that the difference between summer minimum and winter maximum consumption might be very high (between -10 and $+25 \%$ ). George et. al. (2015) report that winter consumption is almost $10 \%$ higher than the summer consumption, exceeding the annual average by $3 \%$, while the summer consumption is $6 \%$ below the average. They claim that the increase in consumption in cold seasons may be a direct consequence of lower outdoor temperatures and the lower temperature of the water in the system. In a study on a plot with LPS buildings, Horkai (2019) found that the difference between winter and summer hot water consumption was $22.45 \%$.

\subsubsection{Monthly domestic hot water consumption}

Monthly consumption averages in the surveyed period (see Fig. 8) show that although outdoor temperature rises at the beginning of the year, DHW consumption also grows and reaches its maximum in February. In spring, DHW consumption decreases, plummeting in May. Minimal consumption occurs in July, and consumption steeply increases in August. In autumn, the consumption increases as the temperature decreases. 


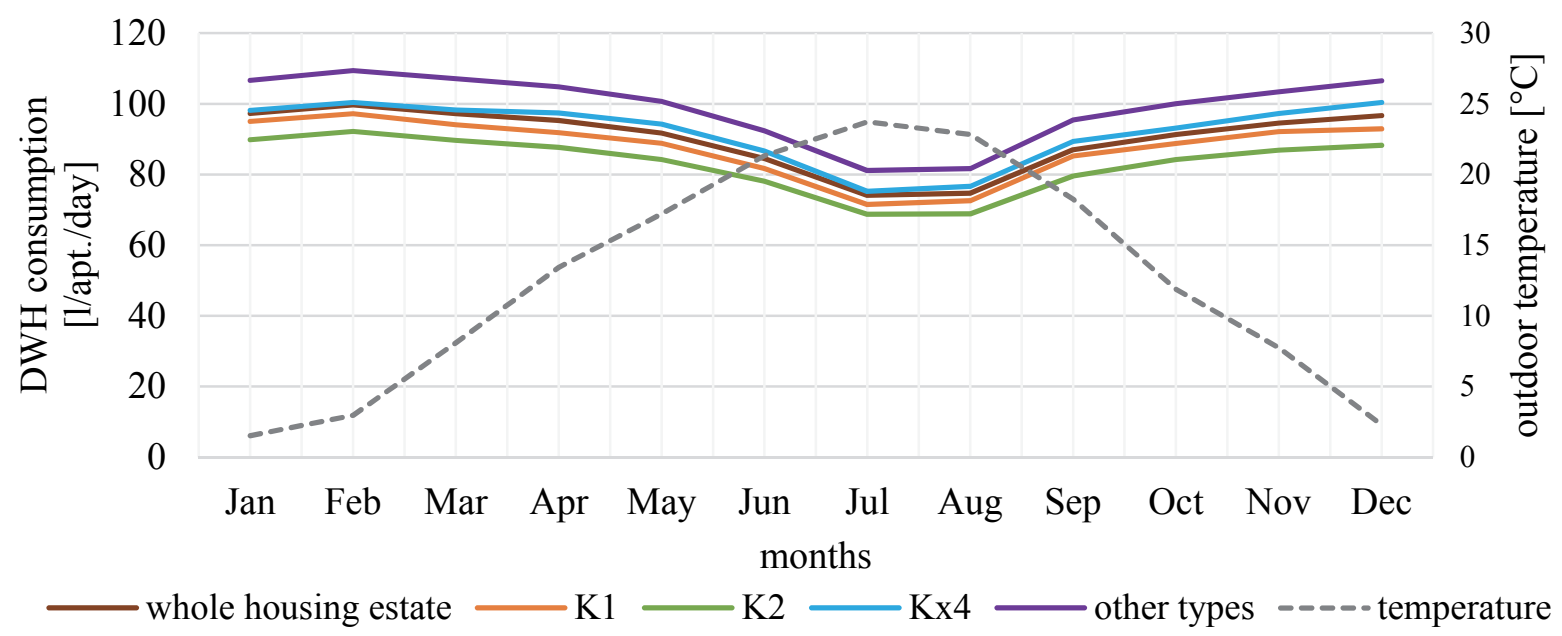

Fig. 8. Yearly pattern of DHW consumption (mean of years 2010-2016).

Ahmed and his colleagues (2015) analyzed Finnish households. The highest DHW consumption was recorded from November to February, while the lowest consumption was from May to July, the two extremes occurring in November and July (Ahmed et al., 2015).

The minimum of DHW consumption in summer may be accounted for by the fact that people tend to go on holiday at this time of the year, and thus the lowest number of people stay at home. Csoknyai and Csoknyai (2014) in their survey of Hungarian LPS buildings found the lowest consumptions in July and August. The reasons for it included holidays and lower needs of consumers (lowest temperature of hot water and shorter bathing time).

A survey conducted on request of the Magyar Turizmus Zrt. in 2003 underpins our findings. They proved that $61 \%$ of trips abroad and $53 \%$ of domestic trips are realized in summer, with an average length of 3.1 nights. Concerning major trips, the temporal distribution of major travels was as follows: $37 \%$ of travellers went for a major trip in July, 29\% in August, and 10\% in June. $79 \%$ of major domestic trips and $67 \%$ of major trips abroad were realized in summer, with an average length of 8.63 nights (M.Á.S.T. Piac- és Közvéleménykutató Társaság, 2004).

\subsection{The model describing the correlation of outdoor temperature and domestic hot water consumption}

The correlation between DHW consumption and weather data was analyzed with regression analysis with two variables. The independent variable was the monthly average temperature, while the dependent variable was DHW consumption.

Table 5 sums up the parameters of the theoretical statistical models described below. All models are significant. Furthermore, the change of outdoor temperature accounts for $\sim 70-74 \%$ of the changes in DHW consumption. 
Table 5. Regression statistics for the analysis of correlations between outdoor temperature and DHW consumption for the units of analysis - linear regression

\begin{tabular}{lccccc}
\hline \hline & $\begin{array}{c}\text { whole housing } \\
\text { estate }\end{array}$ & K1 & K2 & Kx4 & other types \\
\hline \hline $\boldsymbol{R}$ & 0.8611 & 0.8441 & 0.8628 & 0.8595 & 0.8378 \\
$\boldsymbol{R}^{\mathbf{2}}$ & 0.7415 & 0.7125 & 0.7444 & 0.7387 & 0.7019 \\
Adjusted $\boldsymbol{R}^{\mathbf{2}}$ & 0.7384 & 0.7090 & 0.7413 & 0.7355 & 0.6983 \\
Std. error of & 4.4784 & 4.6962 & 4.0490 & 4.4578 & 5.5613 \\
the estimate & 84 & 84 & 84 & 84 & 84 \\
$\boldsymbol{N}$ & 235.2337 & 203.1888 & 238.7789 & 231.8514 & 193.0716 \\
$\boldsymbol{F}$ & $<0.001$ & $<0.001$ & $<0.001$ & $<0.001$ & $<0.001$ \\
Significance & & & & &
\end{tabular}

As a result of regression analysis, based on the table showing coefficients, it can be determined that a $1{ }^{\circ} \mathrm{C}$ rise in outdoor temperature results in an approximately 1 liter $(0.86-1.061)$ decrease in domestic hot water consumption per apartment per day. The values of the curves intersecting the axis show that at $0{ }^{\circ} \mathrm{C}$, the average DHW consumption per flat is between 94.06 and 112.531 (see Table 6).

Table 6. Summary of coefficients for the analysis of correlations between outdoor temperature and DHW consumption for the units of analysis - linear regression

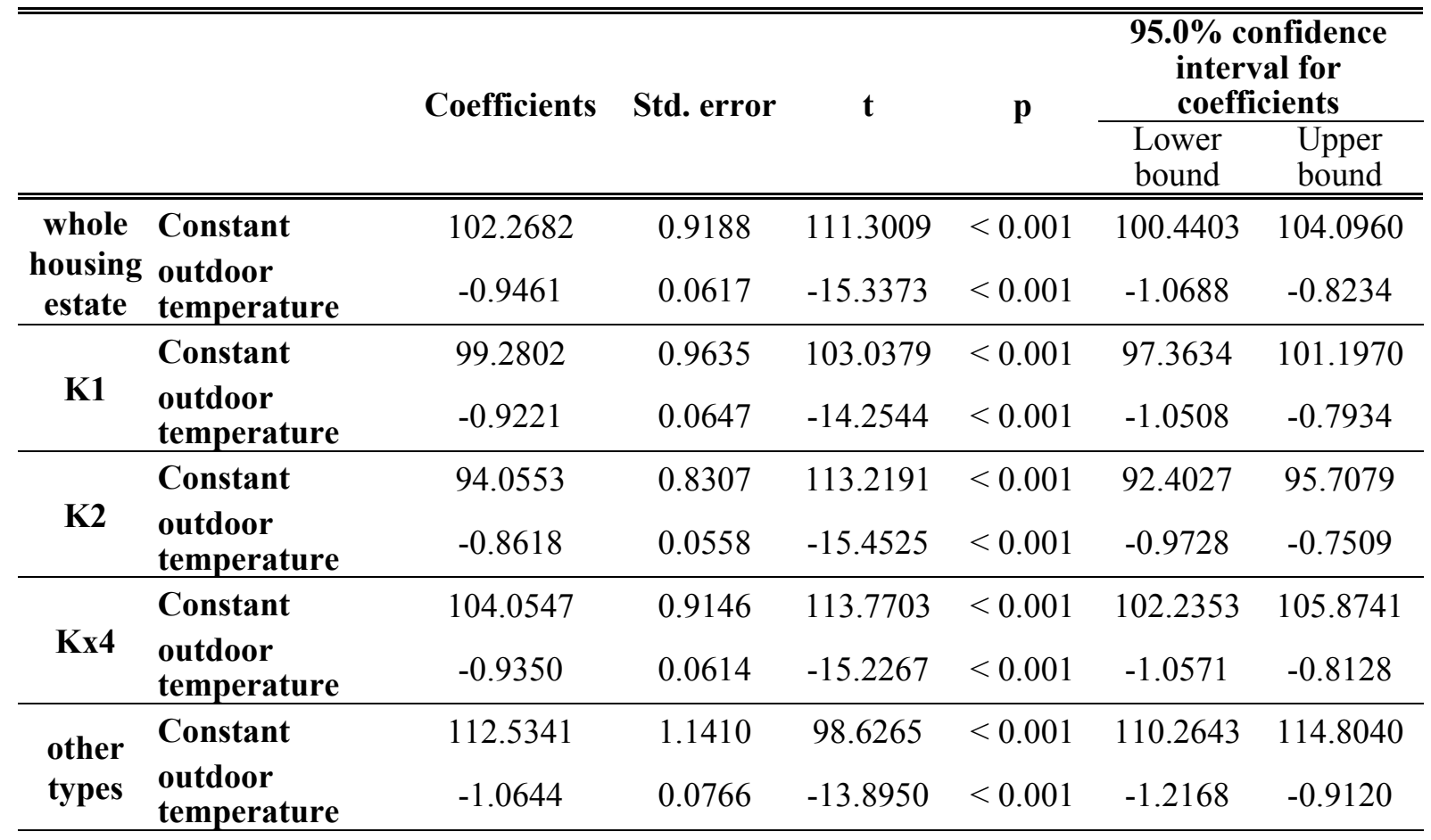


Linear regression functions are shown in Table 7.

Table 7. Summary of regression functions for the analysis of correlations between outdoor temperature and DHW consumption for the units of analysis - linear regression

\begin{tabular}{lc}
\hline \hline spatial level & Regression equation \\
\hline \hline whole housing estate & $y=-0.9461 \times t+102.2682$ \\
K1 & $y=-0.9221 \times t+99.2802$ \\
K2 & $y=-0.8618 \times t+94.0553$ \\
Kx4 & $y=-0.9350 \times t+104.0547$ \\
other types & $y=-1.0644 \times t+112.5341$ \\
\hline
\end{tabular}

where:

$y$ - estimated DHW consumption of the $j$ th month [1/apt/day]

$t$-mean temperature of the $j$ th month $\left[{ }^{\circ} \mathrm{C}\right]$

Fig. 9 shows the values estimated by the linear model and the corresponding measured values, together with the errors for the whole of the housing estate.

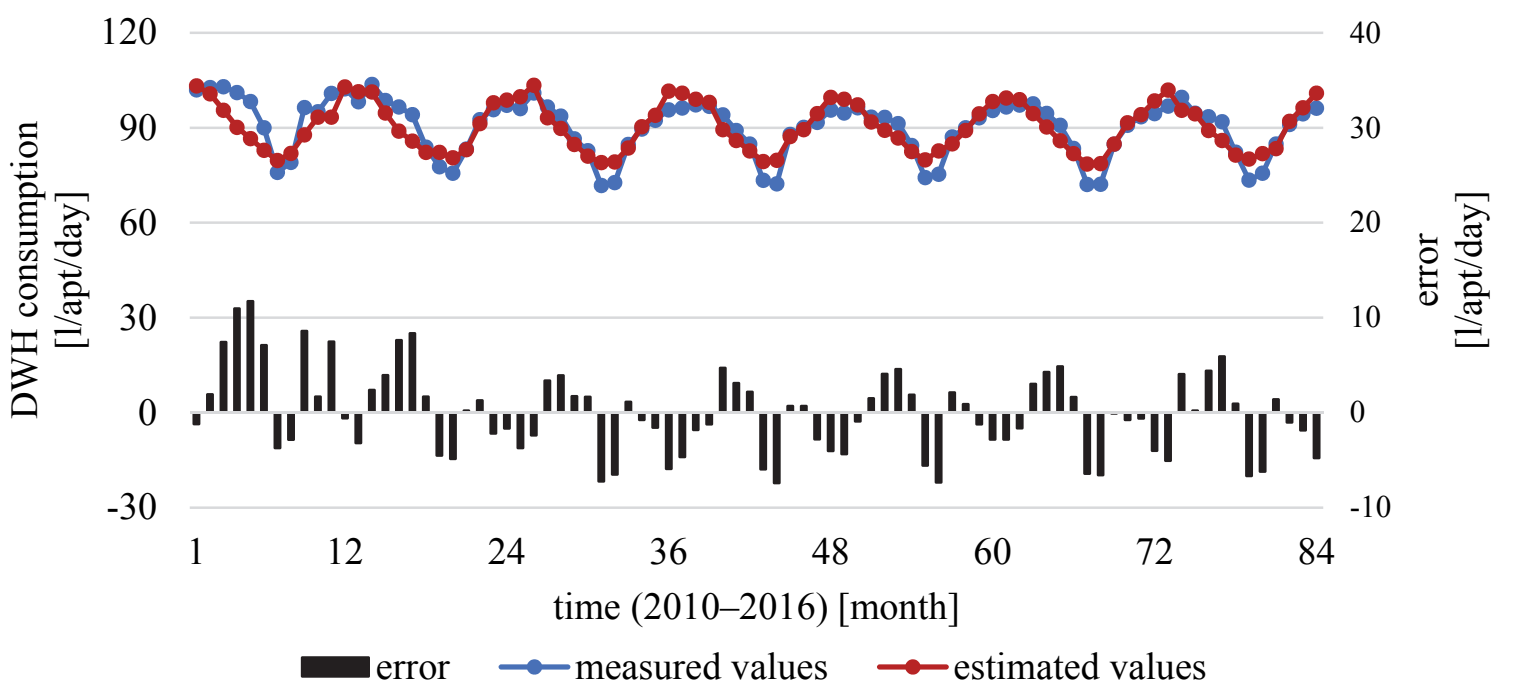

Fig. 9. Values estimated by the linear model of the outdoor temperature and the corresponding measured values, together with the errors. 
Besides the fitting of a linear function, polynomial fitting was also applied in order to test the efficiency of linear fitting. Table 8 shows the quadratic polynomial regression functions and the corresponding $R^{2}$ values. Table 9 shows the cubic polynomial regression functions and the corresponding $R^{2}$ values.

Table 8. Summary of regression functions for the analysis of correlations between outdoor temperature and DHW consumption for the units of analysis - quadratic polynomial regression

\begin{tabular}{llccc}
\hline \hline \multicolumn{1}{c}{ unit } & Regression function & $\boldsymbol{R}^{\mathbf{2}}$ & $\boldsymbol{F}$ & Sig. \\
\hline \hline $\begin{array}{l}\text { whole housing } \\
\text { estate }\end{array}$ & $y=-0.055 \times t^{2}+0.4082 \times t+97.383$ & 0.8532 & 236.3675 & $<0.001$ \\
K1 & $y=-0.0564 \times t^{2}+0.4662 \times t+94.273$ & 0.8312 & 199.4102 & $<0.001$ \\
$\mathbf{K 2}$ & $y=-0.0475 \times t^{2}+0.3086 \times t+89.834$ & 0.8453 & 221.2752 & $<0.001$ \\
$\mathbf{K x 4}$ & $y=-0.0608 \times t^{2}+0.5617 \times t+98.656$ & 0.8779 & 291.1011 & $<0.001$ \\
other types & $y=-0.0603 \times t^{2}+0.4216 \times t+106.19$ & 0.8142 & 164.1521 & $<0.001$ \\
\hline
\end{tabular}

where:

$y$ - estimated DHW consumption of the $j$ th month [1/apt/day]

$t$ - mean temperature of the $j$ th month $\left[{ }^{\circ} \mathrm{C}\right]$

Table 9. Summary of regression functions for the analysis of correlations between outdoor temperature and DHW consumption for the units of analysis - cubic polynomial regression

\begin{tabular}{lcccc}
\hline \hline \multicolumn{1}{c}{ unit } & Regression function & $\boldsymbol{R}^{2}$ & $\boldsymbol{F}$ & Sig. \\
\hline \hline $\begin{array}{l}\text { whole housing } \\
\text { estate }\end{array}$ & $y=-0.0043 \times t^{3}+0.1035 \times t^{2}$ & & & \\
K1 & $-1.0516 \times t+99.5123$ & 0.8843 & 203.8365 & $<0.001$ \\
& $y=-0.0041 \times t^{3}+0.0917 \times t^{2}$ & & & \\
K2 & $-0.8981 \times t+96.2624$ & 0.8587 & 162.0385 & $<0.001$ \\
& $y=-0.0037 \times t^{3}+0.0864 \times t^{2}$ & & & \\
Kx4 & $\quad-0.9252 \times t+91.6332$ & 0.8722 & 181.9718 & $<0.001$ \\
& $y=-0.0039 \times t^{3}+0.0828 \times t^{2}$ & & & \\
other types & $\quad-0.7606 \times t+100.5849$ & 0.9039 & 250.866 & $<0.001$ \\
& $y=-0.0055 \times t^{3}+0.1404 \times t^{2}$ & & & \\
& $-1.4296 \times t+109.8797$ & 0.8504 & 139.4099 & $<0.001$ \\
\hline
\end{tabular}

where:

$y$ - estimated DHW consumption of the $j$ th month [1/apt/day]

$t$ - mean temperature of the $j$ th month $\left[{ }^{\circ} \mathrm{C}\right]$ 
Fig. 10 shows the values estimated by the quadratic polynomial model and the corresponding measured values, together with the errors for the whole of the housing estate.

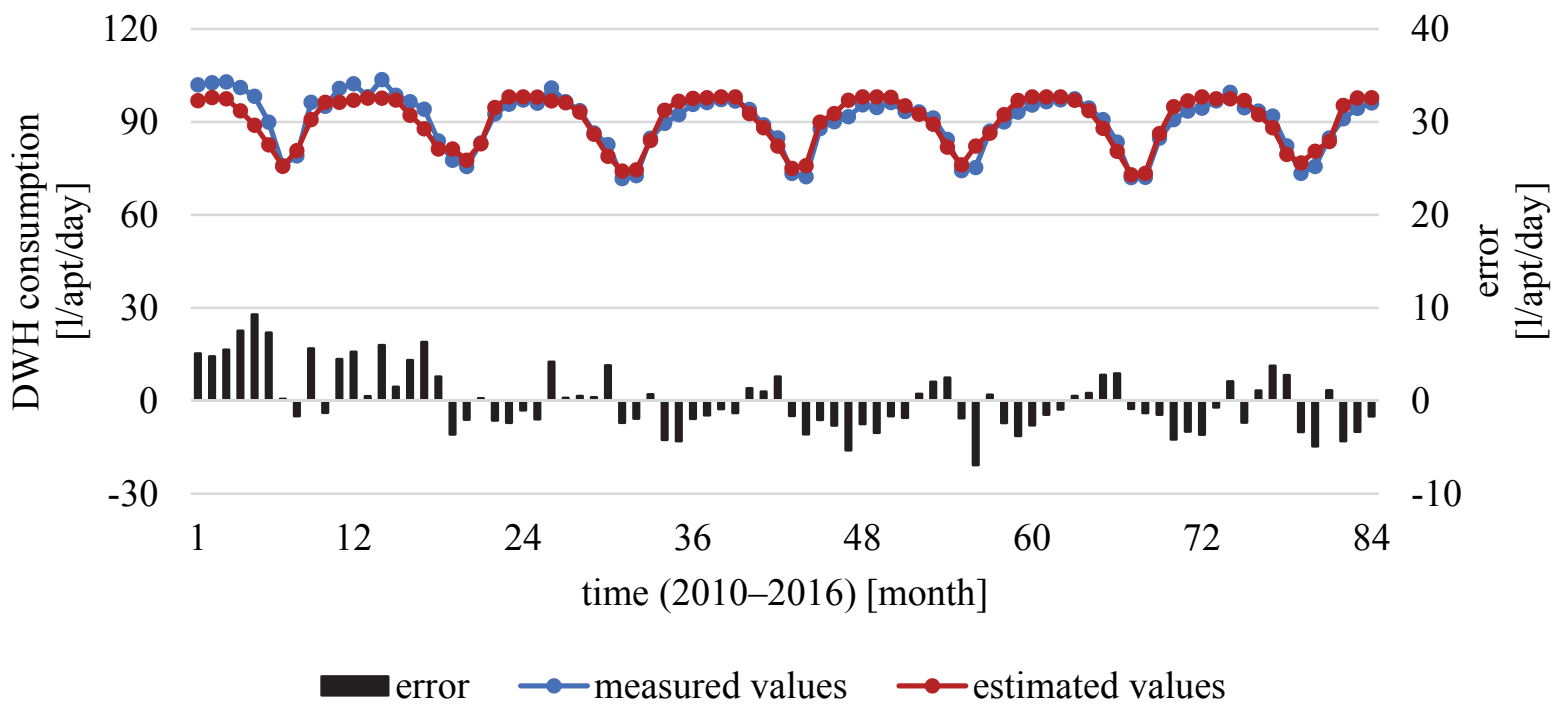

Fig. 10. Values estimated by the quadratic polynomial model of the outdoor temperature and the corresponding measured values, together with the errors

Fig. 11 shows the values estimated by the cubic polynomial model and the corresponding measured values, together with the errors for the whole of the housing estate.

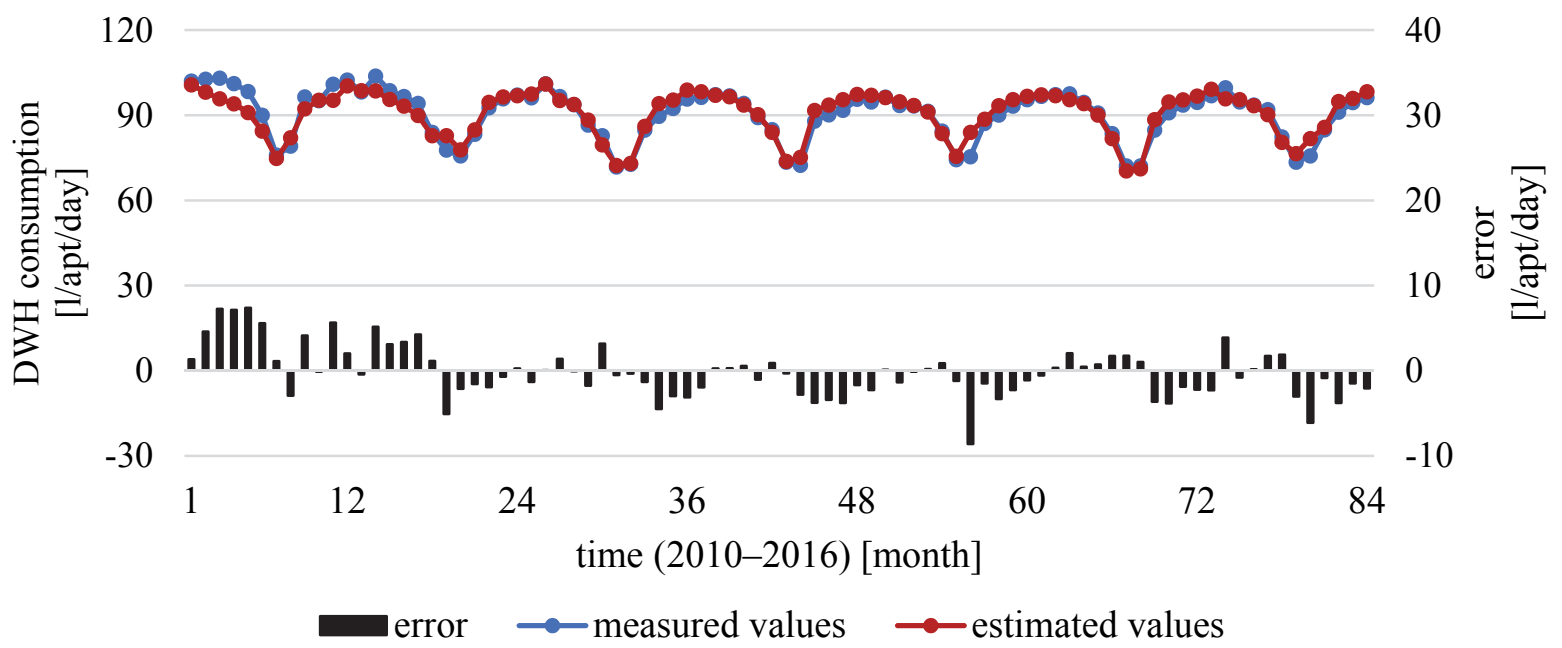

Fig. 11. Values estimated by the cubic polynomial model of the outdoor temperature and the corresponding measured values, together with the errors. 
Fig. 12 illustrates the linear, quadratic, and cubic polynomial functions fitted to the data series of the whole housing estate.

The explanatory force of quadratic and cubic regression functions exceeded by approximately $10-12$ percentage points the $75 \%$ value of the fitted linear curve. This value is higher, i.e., means better fittings, but this does not make the linear model useless, as the difference is not very big.

It must be noted that in the case of estimation, the results are better with polynomial models. However, this is only true if the temperature, i.e., the explanatory variable, is interpreted within the interval experienced up to now (i.e., between -1.2 and $25.1{ }^{\circ} \mathrm{C}$ ), as the behavior of both of the polynomial regression functions is questionable outside this domain. The linear regression functions for each analyzed unit are shown in Fig. 13.

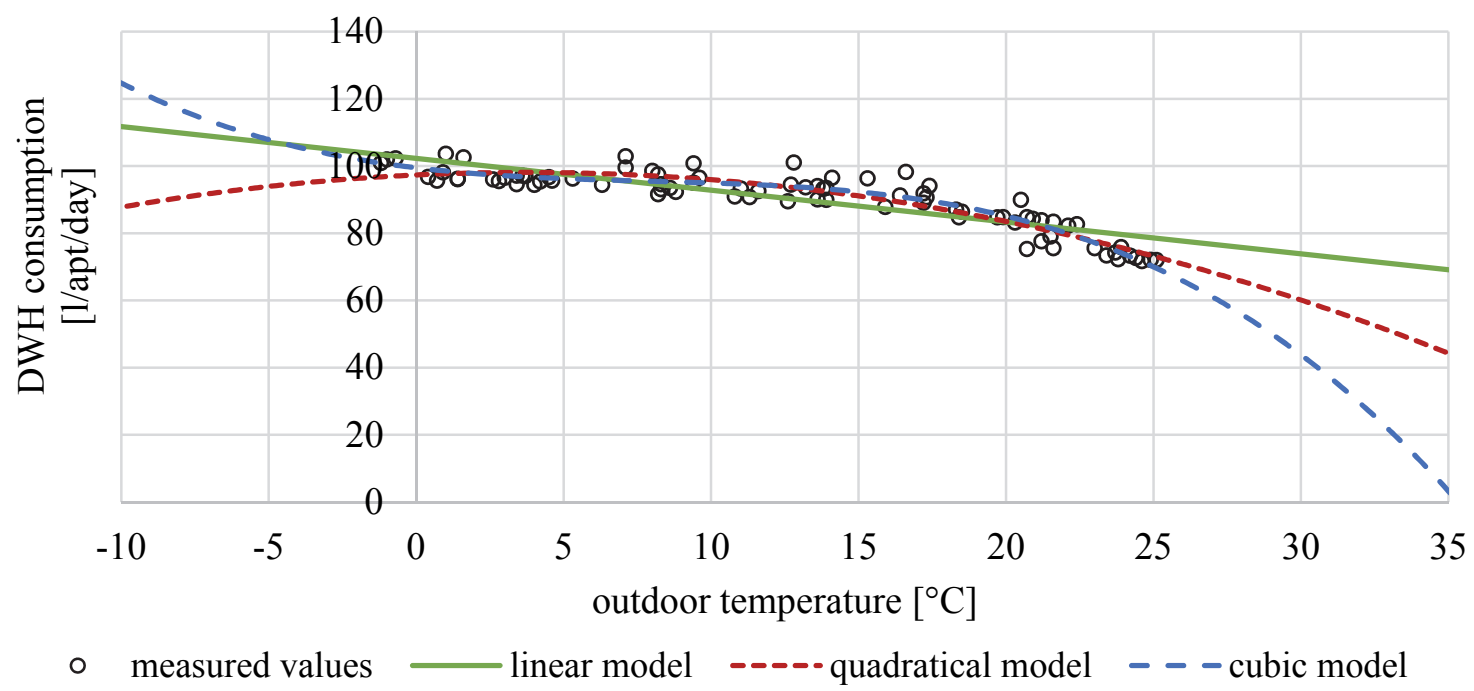

Fig. 12. Regression functions fitted to the data series of the whole housing estate.

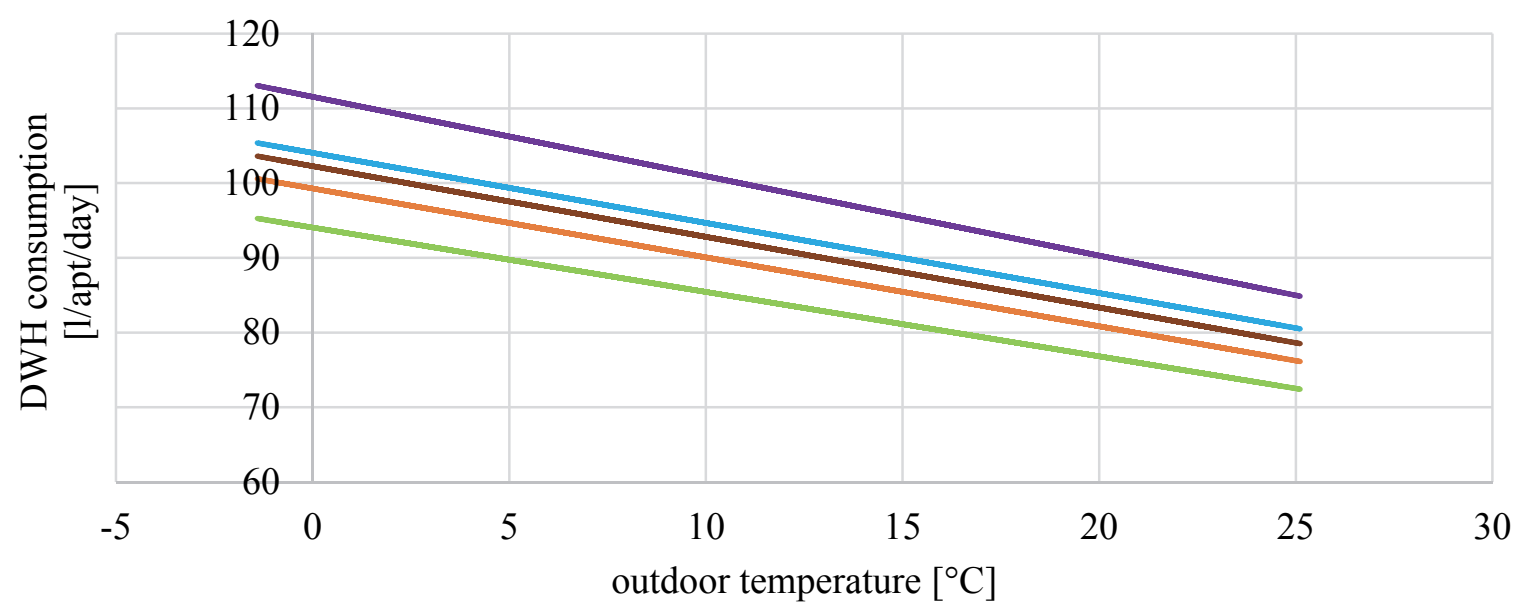

- whole housing estate $-\mathrm{K} 1-\mathrm{K} 2-\mathrm{Kx} 4-$ other types

Fig. 13. Linear regression functions for each unit of analysis. 
In sum, for each unit of analysis, $1{ }^{\circ} \mathrm{C}$ increase in outdoor temperature results in approximately 11 decrease in DHW consumption per apartment per day. The units of analysis react in a similar way to the change in temperature. The corresponding curves are almost parallel, but actually converge towards each other. This is because buildings with a higher consumption will react to temperature change to a higher degree than buildings with a lower consumption. The most favorable type of building concerning DHW consumption per apartment is Type $\mathrm{K} 2$.

By using the established linear or polynomial regression functions, it is possible to estimate the DHW consumption of the apartments or buildings on an outdoor temperature basis, which is most useful for district heat providers.

\subsection{Prognosis based on climate projections}

Based on the linear model described above in Section 5.3 and the climate projections in Section 3.4, future DHW consumption and its possible changes can be estimated in the light of temperature changes. After determining the mean seasonal temperatures based on data from the 2010-2016 period, these temperatures were increased by the expected rise in temperature. The linear model was then applied to these data to determine the expected amount of DHW consumption. The actual data of the 2010-2016 period, and the expected temperatures calculated by two climate models are given in Table 10 below, while the corresponding domestic hot water consumption data are enlisted in Table 11.

Table 10. Predicted mean temperatures $\left({ }^{\circ} \mathrm{C}\right)$ for Hungary based on projections by ALADIN-Climate and RegCM climate models

\begin{tabular}{lccccc}
\hline \hline model & $\begin{array}{c}\text { current } \\
\text { temperature } \\
{\left[{ }^{\mathbf{O}} \mathbf{C}\right]}\end{array}$ & \multicolumn{2}{c}{ ALADIN-Climate (RCP8.5) } & \multicolumn{2}{c}{ RegCM (RCP 4.5) } \\
period & $\begin{array}{c}\text { average of } \\
\mathbf{2 0 1 0}-\mathbf{2 0 1 6} \text { years }\end{array}$ & $\mathbf{2 0 2 1 - 2 0 5 0}$ & $\mathbf{2 0 7 1 - 2 1 0 0}$ & $\mathbf{2 0 2 1 - 2 0 5 0}$ & $\mathbf{2 0 7 1 - 2 1 0 0}$ \\
\hline \hline year & 12.61 & $14.11-14.61$ & $15.61-16.11$ & $13.61-14.11$ & $15.61-16.11$ \\
winter & 2.27 & $3.27-3.77$ & $4.27-4.77$ & $3.27-3.77$ & $5.27-5.77$ \\
spring & 12.92 & $14.42-14.92$ & $15.92-16.42$ & $14.42-14.92$ & $15.42-15.92$ \\
summer & 22.64 & $24.64-25.14$ & $26.64-27.14$ & $23.14-23.64$ & $26.14-26.64$ \\
autumn & 12.63 & $14.13-14.63$ & $15.63-16.13$ & $13.13-13.63$ & $15.63-16.13$ \\
\hline
\end{tabular}


Table 11. Predicted DHW consumption for the whole housing estate (1/apt/day) based on projections by ALADIN-Climate and RegCM climate models

\begin{tabular}{lccccc}
\hline \hline model & $\begin{array}{c}\text { current } \\
\text { consumption } \\
\text { [l/apt/day] } \\
\text { average of }\end{array}$ & ALADIN-Climate (RCP8.5) & RegCM (RCP 4.5) \\
\hline \hline year & 90.34 & $88.44-88.92$ & $87.02-87.50$ & $88.92-89.39$ & $87.02-87.50$ \\
winter & 100.13 & $98.71-99.18$ & $97.76-98.23$ & $98.71-99.18$ & $96.81-97.29$ \\
spring & 90.04 & $88.15-88.62$ & $86.73-87.20$ & $88.15-88.62$ & $87.20-87.68$ \\
summer & 80.85 & $78.49-78.96$ & $76.59-77.07$ & $79.91-80.38$ & $77.07-77.54$ \\
autumn & 90.32 & $88.43-88.90$ & $87.01-87.48$ & $89.38-89.85$ & $87.01-87.48$ \\
\hline
\end{tabular}

As climate projections predict the rising of the mean temperature in all seasons, this should result in a decreasing DHW consumption.

\subsection{Time series decomposition model to describe the correlation of time and domestic hot water consumption}

For the estimation based on the decomposition method presented in Section 4.3, using the trend parameter as the independent variable, the estimated trend values can be produced. If the seasonal deviation of the given month (seasonal deviations are determined by the month, and are uniform across the years) is added to the corresponding trend value, the DHW consumption of the given month is produced (1/apt/day). As the expected value of the random component is zero, it was not employed in the estimation model.

Fig. 14 below shows the seasonal coefficients, i.e., the absolute degree of monthly difference from the annual average of DHW consumption.

The values of the time series decomposition models are given in Table 12 below. All models proved to be significant. 


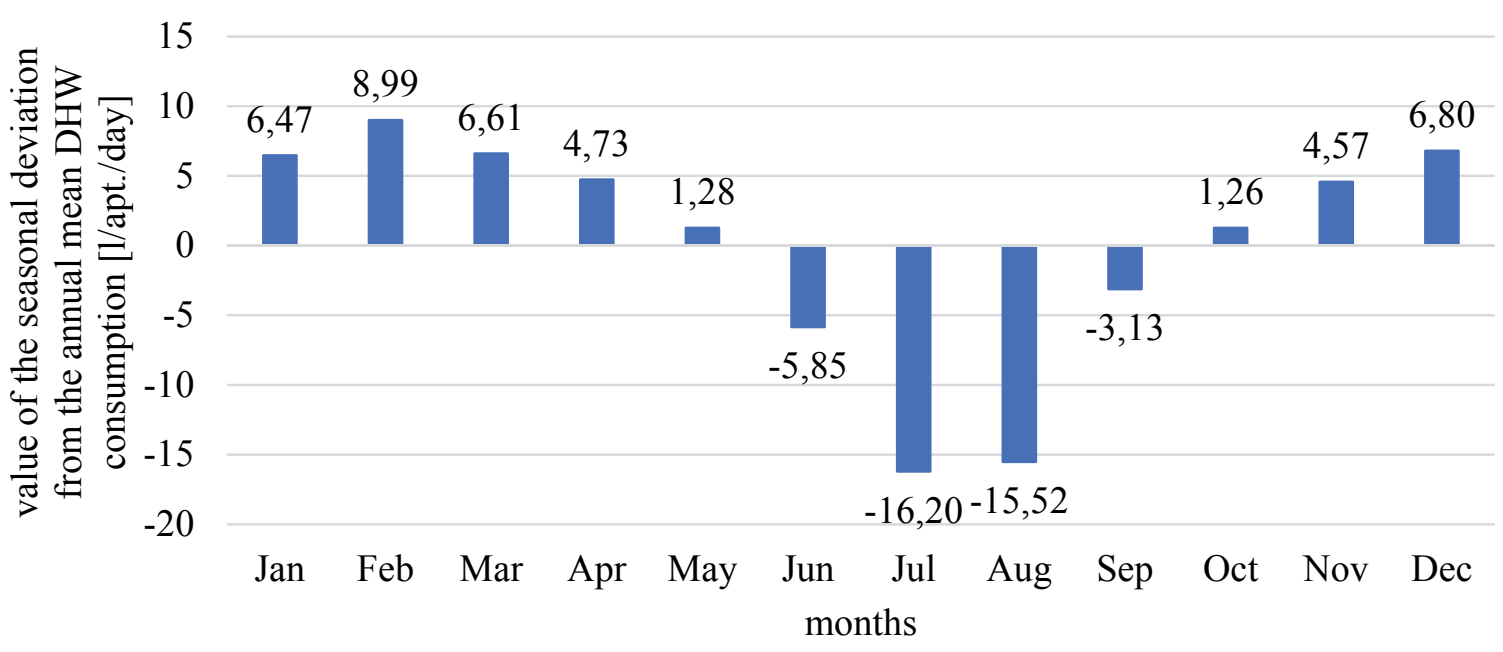

Fig. 14. Seasonal monthly coefficients of DHW consumption - whole housing estate.

Table 12. Statistical values for the analysis of the correlation between time and DHW consumption - time series decomposition model

\begin{tabular}{lccccc}
\hline \hline & $\begin{array}{c}\text { whole } \\
\text { housing estate }\end{array}$ & K1 & K2 & Kx4 & other types \\
\hline \hline $\boldsymbol{R}$ & 0.9677 & 0.9418 & 0.9745 & 0.9694 & 0.9418 \\
$\boldsymbol{R}^{2}$ & 0.9365 & 0.8870 & 0.9496 & 0.9397 & 0.8871 \\
Adjusted $\boldsymbol{R}^{2}$ & 0.9258 & 0.8679 & 0.9411 & 0.9296 & 0.8680 \\
Std. error of the & 2.3849 & 3.1817 & 2.1249 & 2.3237 & 3.1813 \\
estimate & 84 & 84 & 84 & 84 & 84 \\
$\boldsymbol{N}$ & 87.3006 & 46.4596 & 111.51 & 92.2791 & 46.4725 \\
$\boldsymbol{F}$ & $<0.001$ & $<0.001$ & $<0.001$ & $<0.001$ & $<0.001$ \\
Significance & & & &
\end{tabular}

Owing to the high $R^{2}$ values, the estimations given by the model can be considered good for a one-year-long time span (compared to the baseline period 2010-2016); for the following 2 years it can be regarded reliable; while on the long run (in 5 years or later) the results must be considered with reservations.

The regression coefficients of each unit of analysis are given in Table 13. 
Table 13. Summary of coefficients for the analysis of the correlation between time and DHW consumption - time series decomposition model

\begin{tabular}{|c|c|c|c|c|c|c|c|}
\hline \multirow{2}{*}{ unit } & & \multirow{2}{*}{ Coefficients } & \multirow{2}{*}{ Std. error } & \multirow{2}{*}{$t$} & \multirow{2}{*}{$p$} & \multicolumn{2}{|c|}{$\begin{array}{c}95.0 \% \text { Confidence } \\
\text { interval for coefficients }\end{array}$} \\
\hline & & & & & & $\begin{array}{l}\text { Lower } \\
\text { bound } \\
\end{array}$ & $\begin{array}{l}\text { Upper } \\
\text { bound } \\
\end{array}$ \\
\hline \multirow{2}{*}{$\begin{array}{l}\text { whole } \\
\text { housing } \\
\text { estate }\end{array}$} & Constant & 93.7172 & 1.8912 & 49.5550 & $<0.001$ & 89.9551 & 97.4794 \\
\hline & $\begin{array}{l}\text { ID of the } \\
\text { month }\end{array}$ & -0.0796 & 0.0387 & -2.0599 & $<0.001$ & -0.1565 & -0.0027 \\
\hline \multirow[b]{2}{*}{ K1 } & Constant & 89.8079 & 1.9087 & 47.0515 & $<0.001$ & 86.0109 & 93.6050 \\
\hline & $\begin{array}{l}\text { ID of the } \\
\text { month }\end{array}$ & -0.0508 & 0.0390 & -1.3024 & $<0.001$ & -0.1284 & 0.0268 \\
\hline \multirow[b]{2}{*}{ K2 } & Constant & 86.2103 & 1.7208 & 50.0991 & $<0.001$ & 82.7871 & 89.6335 \\
\hline & $\begin{array}{l}\text { ID of the } \\
\text { month }\end{array}$ & -0.0712 & 0.0352 & -2.0247 & $<0.001$ & -0.1412 & -0.0012 \\
\hline \multirow[b]{2}{*}{ Kx4 } & Constant & 93.6914 & 1.9116 & 49.0124 & $<0.001$ & 89.8886 & 97.4941 \\
\hline & $\begin{array}{l}\text { ID of the } \\
\text { month }\end{array}$ & -0.0337 & 0.0391 & -0.8616 & $<0.001$ & -0.1114 & 0.0441 \\
\hline \multirow{2}{*}{$\begin{array}{l}\text { other } \\
\text { types }\end{array}$} & Constant & 104.5262 & 2.1342 & 48.9757 & $<0.001$ & 100.2805 & 108.7719 \\
\hline & $\begin{array}{l}\text { ID of the } \\
\text { month }\end{array}$ & -0.1275 & 0.0436 & -2.9231 & $<0.001$ & -0.2143 & -0.0407 \\
\hline
\end{tabular}

The general equation of the time series decomposition model is

$$
Y_{i, j}=T_{i, j}+S_{j}+E_{i, j}
$$

where

$Y_{i, j}$ is the estimated DHW consumption of the $j$ th month of the $i$ th year (1/apt/day), $T_{i, j}$ is the estimated trend value of DHW consumption of the $j$ th month of the $i$ th year,

$S_{j}$ is the seasonal component of the $j$ th month, $E_{i, j}$ is the error component $j$ th month of the $i$ th year (expected value: 0 ).

For example, the values in Equation (1) are as follows for the whole housing estate for January 2017 (month 85, counting from January 2010):

$$
Y_{i, j}=93.7172-0.0796 * 85+6.47=93.4180 .
$$


Fig. 15 illustrates the DHW consumption values measured in the survey period (2010-2016) and the estimated values for years 2017-2019 for the whole housing estate.

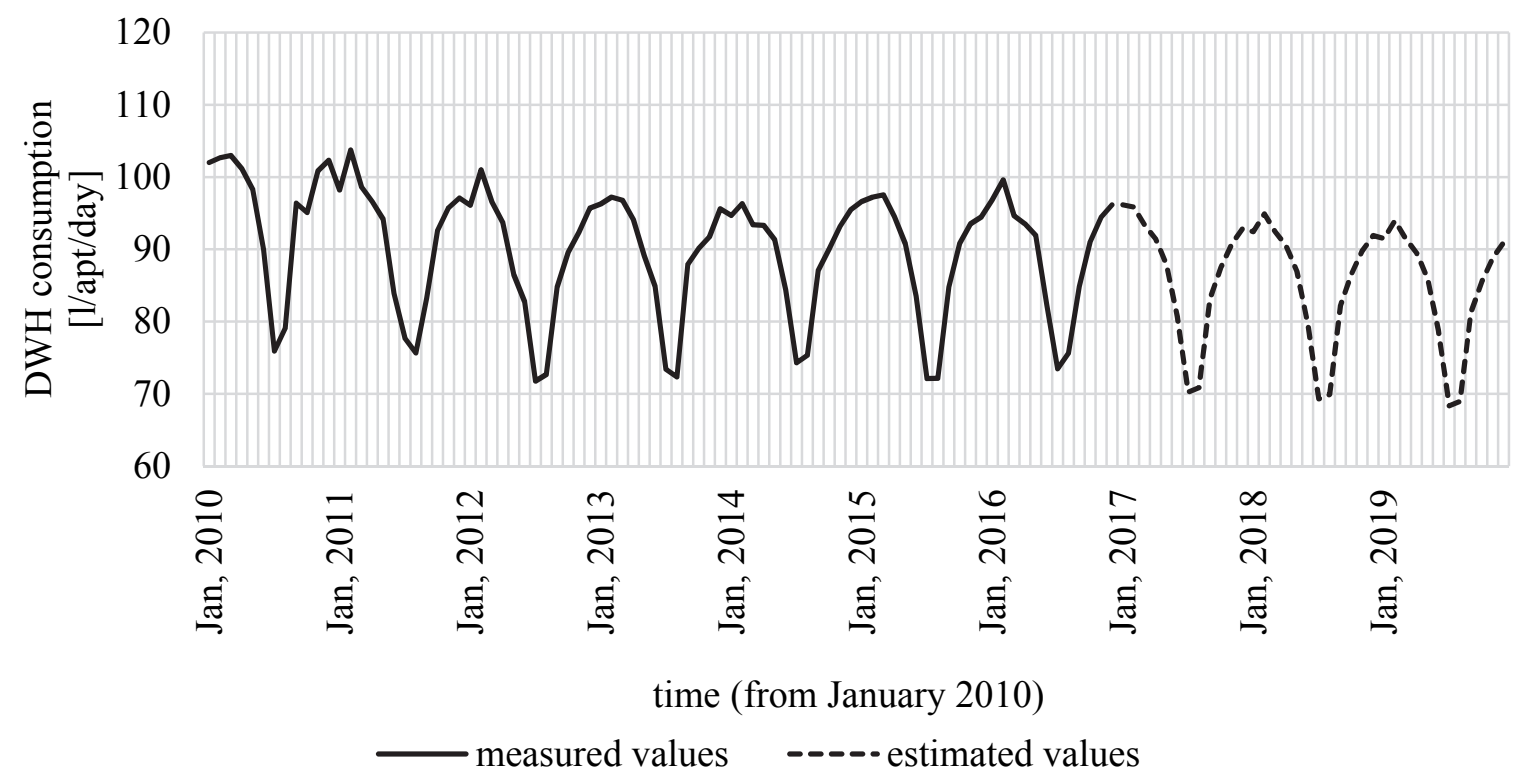

Fig. 15. Measured and estimated DHW consumption values by the time series decomposition model - whole housing estate.

Using the model based on the time series analysis created, it is possible to estimate the DHW consumption per apartment per day for any future month, which could be a basic operational planning data for district heating providers. The model takes into account both the expected outdoor temperature for the month and the typical domestic hot water consumption values for that month (absolute deviations from the annual mean consumption). By extending the available time series (e.g., by including data after 2016), the accuracy of the model can be verified and refined as needed.

\section{Conclusion and directions for future research}

This study surveyed how changes in outdoor temperature influence domestic hot water consumption in a housing estate of LPS buildings in Budapest, Hungary with the help of statistical analyses of DHW consumption data and changes in mean temperatures. The urban heat island effect is very significant in the investigated Füredi housing estate, therefore, it is especially important to analyze the energy consumption of people living in this type of building. 
The results have proved that changes in the outdoor temperature significantly influence the DHW consumption. The model created by regression analysis estimates DHW consumption based on outdoor temperature data, and accounts for $74 \%$ of the measured values. It has been found that a $1{ }^{\circ} \mathrm{C}$ rise in the mean outdoor temperature results in an approximately $11 /$ apt/day decrease in DHW consumption. Furthermore, if the outdoor mean temperature is $0^{\circ} \mathrm{C}$, DHW consumption is between 94-112 1/apt/day. These values can be regarded as a rule of thumb for estimating DHW consumption.

Given that the explanatory force of the linear model is $74 \%$, it can be seen, that other factors than outdoor temperature influence the seasonality and consumption values seen in DHW usage. By including additional independent variables - e.g., from the holistic model of factors influencing energy consumption -, the explanatory force of the model can be increased. This study is an outdoor temperature-based estimation for DHW consumption. A different method, which has no impact on the outdoor temperature-based estimation could be a home-stay-based estimation, in which it could be analyzed, how the number and proportion of working days and holidays affect the DHW consumption in each year.

Based on the analysis of DHW consumption broken down to seasons and months, the seasonal coefficient for each month was determined. Using the time series decomposition model, the expected daily DHW consumption of a flat of a given future month in the near future can be estimated with $94 \%$ reliability.

The same data series may be analyzed in the future by a stochastic time series analysis, or a polynomial trend might be fitted to the data instead of a linear one in the time series decomposition model. The present study did not take into account whether the building envelop had been energetically refurbished. This factor may also be researched.

Acknowledgments: The author thanks FÖTÁV Budapest Távhőszolgáltató Zrt. (Budapest District Heating Works Private Company Limited by Shares) for making the data available for research. Special thanks to Zsolt Ónodi and Csenge Dian for their useful comments on the draft of this article.

Comments: The map shown in Fig. 2 was edited using official basic data. Permit for using the data: FF/947/1/2017 by the Földmüvelődésügyi Minisztérium (Ministry of Agriculture). Source of further data: OpenStreetMap. The present study used the datasets of the Hungarian Meteorological Service (OMSZ). Registration number: GFO-456-2/2018, code: H/27.

Conflicts of Interest: The authors declare no conflict of interest.

\section{References}

7/2006. (V. 24.) TNM rendelet az épületek energetikai jellemzőinek meghatározásáról - ENG: 7/2006. (V. 24.) Decree of the Minister without Portfolio on the determination of the energy characteristics of buildings. (2006).

Abrams, D.W., and Shedd, A.C., 1996: Effect of seasonal changes in use patterns and cold inlet water temperature on water-heating loads. United States: American Society of Heating, Refrigerating and Air-Conditioning Engineers, Inc., Atlanta, GA (United States). 
Ahmed, K., Pylsy, P., and Kurnitski, J., 2015: Monthly domestic hot water profiles for energy calculation in Finnish apartment buildings. Energ. Build. 97, 77-85.

https://doi.org/10.1016/j.enbuild.2015.03.051

Ahmed, K., Pylsy, P., and Kurnitski, J., 2016: Hourly consumption profiles of domestic hot water for different occupant groups in dwellings. Solar Energy 137, 516-530.

https://doi.org/10.1016/j.solener.2016.08.033

Balázs, P., Bácskay, A., Boros, J., Kemény, R., Székely, G., and Vargha, L., 2017: Ezüstkor: korosodás és társadalom.KSH, Budapest. (in Hungarian)

Baumann, M., Csoknyai, T., Kalmár, F., Magyar, Z., Majoros, A., Osztroluczky, M., . . Zöld, A. 2009: Épületenergetika (Ed. Baumann M.): Pécsi Tudományegyetem Pollack Mihály Müszaki Kar. (In Hungarian)

Beck, H., Zimmermann, N., McVicar, T., Vergopolan, N., Berg, A., and Wood, E., 2018: Present and future Köppen-Geiger climate classification maps at 1-km resolution. Scientific Data 5, 180214. https://doi.org/10.1038/sdata.2018.214

Becker, B.R. and Stogsdill, K.E. (1990a). Development of a hot water use data base. Paper presented at the Annual meeting of the American Society of Heating, Refrigerating and Air-Conditioning Engineers (ASHRAE), St. Louis, Missouri, United States, 9-13 Jun 1990.

Becker, B.R. and Stogsdill, K.E., 1990b: A Domestic Hot Water Use Database: Identifying the factors that influence domestic hot water use can help develop more efficient systems. ASHRAE Transactions 32(9), 21-25.

Berza, L. 1993: Budapest Lexikon. Budapest: Akadémiai Kiadó.(In Hungarian)

Birghoffer, P. and Hikisch, L. 1994: A panelos lakóépületek felújítása. Budapest: Müszaki Könyvkiadó. (In Hungarian)

Csima, G. and Horányi, A., 2008: Validation of the ALADIN-Climate regional climate model at the Hungarian Meteorological Service. Idöjárás 112, 155-177.

Csoknyai, I. and Csoknyai, T., 2014: A HMV hő- és vízfogyasztás vizsgálata panelépületeknél. Magyar Épületgépészet 2014/6, 19-21. (In Hungarian)

Dési, A. 1996: Panelkalauz. Budapest: Építésügyi Tájékoztatási Központ Kft. (In Hungarian)

Dian, C., Pongrácz, R., Dezsö, Z., and Bartholy, J., 2020: Annual and monthly analysis of surface urban heat island intensity with respect to the local climate zones in Budapest. Urban Climate 31, 100573. https://doi.org/10.1016/j.uclim.2019.100573

Egyedi, L. 1963: Épületgépészeti kézikönyv I. Budapest: Müszaki Könyvkiadó. (In Hungarian)

Energia Klub., 2004: Hol szökik az energia? Mit tehetünk a háztartási energiafelhasználás csökkentésért? (In Hungarian)

Retrieved from: https://www.energiaklub.hu/dl/kiadvanyok/holszokikazenergia.pdf

Energiaoldal, 2012: Akár a jövedelem felét is elviszi a lakásrezsi Magyarországon. (In Hungarian) Retrieved from https://energiaoldal.hu/akar-a-jovedelem-felet-is-elviszi-a-lakasrezsi-magyarorszagon/

Energy Monitoring Company, 2008: Measurement of Domestic Hot Water Consumption in Dwellings. Retrieved from https://assets.publishing.service.gov.uk/government/uploads/system/uploads/ attachment_data/file/48188/3147-measure-domestic-hot-water-consump.pdf

Eurostat. Final energy consumption by sector. Retrieved from: https://ec.europa.eu/eurostat/databrowser/view/ten00124/default/table?lang=en

Gál, T., Bechtel, B., and Unger, J., 2015: Comparison of two different Local Climate Zone mapping methods. Paper presented at the ICUC9 - 9th International Conference on Urban Climate jointly with 12th Symposium on the Urban Environment, Toulouse, France, (20-24 July 2015).

George, D., Pearre, N., and Swan, L., 2015: High resolution measured domestic hot water consumption of Canadian homes. Energ. Build. 109, 304-315.

https://doi.org/10.1016/j.enbuild.2015.09.067

Gerin, O., Bleys, B., and De Cuyper, K., 2014: Seasonal variation of hot and cold water consumption in apartment buildings. Paper presented at the CIBW062 Symposium 2014, São Paulo, Brasil, (8-10 September 2014).

Hakala, J., 2015: Energy consumption in households 2014. Retrieved from Helsinki: https://www.stat.fi/til/asen/2014/asen_2014_2015-11-20_en.pdf

Hobbi, A. and Siddiqui, K., 2009: Optimal design of a forced circulation solar water heating system for a residential unit in cold climate using TRNSYS. Solar Energy 83, 700-714. 
https://doi.org/10.1016/j.solener.2008.10.018

Hong, T., Yan, D., D'Oca, S., and Chen, C.f., 2017: Ten questions concerning occupant behavior in buildings: The big picture. Build. Environ. 114, 518-530.

https://doi.org/10.1016/j.buildenv.2016.12.006

Horkai, A., 2019: Lakossági hideg- és melegvíz fejadagok tervezési értékeinek vizsgálata a múltban és a jelenben. Magyar Épületgépészet 2019/7-8, 17-21. (In Hungarian)

Horkai, A., Khaut, N., and Nagy, Z., 2019: A Zuglói lakótelep felújítási energiapotenciál becslése. Magyar Épületgépészet 2019/3, 9-13. (In Hungarian)

Horkai, A., and Kiss, G., 2019: Használatimelegvíz-felhasználást befolyásoló egyéni keretfeltételek statisztikai elemzése. Magyar Energetika 2019/5, 6-14. (In Hungarian)

Horváth, M., Csoknyai, T., and Szánthó, Z., 2016: Panelépületek használati melegvíz hőfelhasználásának számítása. Magyar Épületgépészet 2016/7-8, 8-11. (In Hungarian)

Kajner, P., Czira, T., Selmeczi, P., and Sütö, A., 2017: National adaptation geo-information system in climate adaptation planning. Idojaras 121, 345-370.

Kocsis, K. 2018: Magyarország nemzeti atlasza 2. kötet. Természeti környezet. Budapest: Magyar Tudományos Akadémia, Csillagászati és Földtudományi Kutatóközpont, Földrajztudományi Intézet. (In Hungarian)

Kowsari, R. and Zerriffi, H., 2011: Three dimensional energy profile:: A conceptual framework for assessing household energy use. Energy Policy 39, 7505-7517. https://doi.org/10.1016/j.enpol.2011.06.030

Központi Statisztikai Hivatal. 2014: 12. Lakásviszonyok. Budapest: Központi Statisztikai Hivatal. (In Hungarian)

M.ÁS.T. Piac- és Közvéleménykutató Társaság. (2004). Összefoglaló. Retrieved from https://adoc.pub/sszefoglalo-keszitette-a-magyar-turizmus-rt-kutatasi-igazgat.html (In Hungarian)

Magyar Energetikai és Közmü-szabályozási Hivatal. Az egyes ágazatok részesedése a végső energiacélú felhasználásból. (In Hungarian) Retrieved from http://mekh.hu/az-egyes-agazatok-reszesedese-avegso-energiacelu-felhasznalasbol? $\mathrm{f}=0$

March, H. and Sauri, D., 2010: The Suburbanization of Water Scarcity in the Barcelona Metropolitan Region: Sociodemographic and Urban Changes Influencing Domestic Water Consumption. The Professional Geographer 62, 32-45. https://doi.org/10.1080/00330120903375860

Menyhárt, J. 1977: Az épületgépészet kézikönyve. Budapest: Műszaki Könyvkiadó. (In Hungarian)

Meyer, J., 2000: A review of domestic hot water consumption in South Africa. Res. Develop. J. 16, $55-61$.

NAHB Research Center, 2002: Domestic Hot Water System Modeling for the Design of Energy Efficient Systems. Retrieved from: https://www.homeinnovation.com/ /media/Files/Reports/domestichotwater.pdf

Nemzeti Alkalmazkodási Térinformatikai Rendszer (NATéR) - ENG: National Adaptation Geoinformation System (NAGiS). Retrieved from https://map.mbfsz.gov.hu/nater/

Otaki, Y. 2003) Residential water demand analysis by household activities. Paper presented at the 2nd International Conference on Efficient Use and Management of Water for Urban Supply, Tenerife, Canary Islands, Spain, (2-4 April 2003).

Pérez-Lombard, L., Ortiz, J., and Pout, C., 2008: A review on buildings energy consumption information. Energy and Buildings 40(3), 394-398. doi:https://doi.org/10.1016/j.enbuild.2007.03.007

Perlman, M. and Mills, B.E., 1985: Development of residential hot water use patterns. ASHRAE Transactions 91, 657-679.

Putzer, P., and Pavluska, V., 2013: Szakirodalmi összefoglaló az energia- és alternatív energiafogyasztás Magyarországon témakörében. (In Hungarian) Retrieved from:

https://ktk.pte.hu/sites/ktk.pte.hu/files/images/szervezet/intezetek/mti/putzer_pavluska_ szakirodalmi_osszefoglalo_az_energia_es_alternativ_energiafogyasztas_magyarorszagon temakoreben 2013.pdf

Romano, G., Salvati, N., and Guerrini, A., 2016: An empirical analysis of the determinants of water demand in Italy. J. Cleaner Product. 130, 74-81.

https://doi.org/10.1016/j.jclepro.2015.09.141 
Sitz, L., Di Sante, F., Farneti, R., Fuentes Franco, R., Coppola, E., Mariotti, L., . . Giorgi, F., 2017: Description and evaluation of the Earth System Regional Climate Model (RegCM-ES). $J$. Adv.Modeling Earth Syst. 9, 1863-1886. doi:https://doi.org/10.1002/2017MS000933

Young, C., Davis, M., McNeill, I., Malhotra, B., Russell, S., Unsworth, K., and Clegg, C., 2013: Changing Behaviour: Successful Environmental Programmes in the Workplace. Business Strat. the Environ.t 24. https://doi.org/10.1002/bse.1836 